\title{
Alien fish, amphibian and reptile species in Romania and their invasive status: a review with new data
}

\author{
Alexandru Iftime $e^{1}$ Oana Iftime ${ }^{2}$ \\ 1 "Grigore Antipa" National Museum of Natural History, 1 Kiseleff, 011341 Bucharest, Romania \\ 2 Independent researcher, Str. Iuliu Maniu 65, București, România \\ Corresponding author: Alexandru Iftime (aiftime@antipa.ro)
}

Received 19 April 2021 | Accepted 7 June 2021 | Published 30 June 2021

Citation: Iftime A, Iftime O (2021) Alien fish, amphibian and reptile species in Romania and their invasive status: a review with new data. Travaux du Muséum National d'Histoire Naturelle “Grigore Antipa” 64(1): 131-186. https:// doi.org/10.3897/travaux.64.e67558

\begin{abstract}
The paper presents a review of literature data, supplemented with original observations, on the presence, establishment, distribution and invasive status of alien fish, amphibian and reptile species in Romania. Consistent criteria were followed in defining alien species records, establishment and invasive status. From the 48 alien fish species, 1 fish hybrid, 1 amphibian and 18 reptile species recorded, only 16 fishes and 3 reptiles can be regarded as established. Of these we consider the criteria for invasive status as being probably fulfilled by one fish species (Perccottus glenii), and less likely by six more fish species. The presence and the alien status of the one amphibian are debatable. No reptile species can be considered invasive at present.
\end{abstract}

\section{Keywords}

Alien species, fishes, amphibians, reptiles, presence, establishment, invasive status.

\section{Introduction}

The alien, or non-native, species are of increasing concern for conservation-oriented management all over the world. Indeed, some introduced species have wrought havoc across ecosystems in various places and caused significant reduction in the native ones, even extinction, especially in vulnerable insular situations (see, e.g., BirdLife International 2016; Wyatt et al. 2008). However, introduction of species is 
a common phenomenon and there is a considerable range of potential results, in terms of ecological significance and impact. Firstly, not all introductions succeed in establishing viable populations, and even established populations of non-native species are not inherently destructive or "invasive", there being numerous instances where their ecological impact is neutral or negligible (Copp et al. 2005). There is considerable discussion about the average rate of success of alien species (i.e. species introduced to a non-native setting) but it may range from ca. 10\% (Williamson and Fitter 1996) to ca. 50\% (Jeschke and Strayer 2005) for each adaptation/expansion "step" - being usually considered three major such "steps": "escaping", "establishing" and "becoming a pest" (Williamson and Fitter 1996). For Romania, there are numerous efforts to list and discuss non-native/invasive species (e.g. Anastasiu et al. 2016; Anastasiu et al. 2017; Stănescu et al. 2020), some focused upon fishes as a group of particular interest, with numerous introduced and acclimatized species (Manea 1985; Gavriloaie et al. 2003; Gavriloaie 2007; Iacob and Petrescu-Mag 2008; Gavriloaie and Berkesy 2013; Gavriloaie et al. 2015 etc.). However, the criteria used for listing species are variable, some, for instance, including (e. g. Iacob and Petrescu-Mag 2008) and some excluding (e.g. Stănescu et al. 2020) non-native species that only survive in thermal waters; variable therefore being also the contents of the national lists of introduced species. We have endeavoured to introduce a consistent set of criteria, and to discuss the current distribution and situation of non-native fish, amphibian and reptile species in Romania, using both literature references and the result of personal observations.

\section{Materials and methods}

We have searched the literature pertaining to introduced fish, amphibian and reptile species for Romania, including non-technical (especially inasmuch as they present imagery that can be checked) and online publications (introductions of alien forms/ subspecies of species natively occurring in Romania have not been considered ${ }^{1}$ ). Species considered are those that have either been found free-ranging, even as a single specimen, without known ownership, or are/were being kept under open, pond- or basin-based farming conditions (from which escape or release is theoretically possible) or are known from immediately outside Romania from ecosystems (such as a river channel) which are contiguous to Romanian ones and are likely, or could be expected to, occur on the Romanian side also. Transient introductions that cannot survive over the winter, or introductions limited to thermal waters, have also been considered. Practically we have chosen to treat all introductions outside of zoological collections and indoors farming, thus being able to cover species such as Parabramis pekinensis which are treated by most authors (e. g. Manea 1985; Gavriloaie et al. 2003;

1 However, we have discussed instances of alien forms that are most often treated as distinct species from their native Romanian counterparts, but that can be argued to be conspecific with these. 
Gavriloaie 2007; Iacob and Petrescu-Mag 2008; Gavriloaie et al. 2015; Stănescu et al. 2020) although they were only transiently present in Romania, in pond-based aquaculture (Iacob and Petrescu-Mag 2008; Gavriloaie et al. 2015). However, we introduce a discussion of the current status and spread that attempts to clarify which species are still present and where, precisely. Personal records are integrated into this discussion, with mention of observation year. Also, data from the collection of the "Grigore Antipa" National Museum of Natural History were used. Classification is after Fricke et al. 2021 and van der Laan et al. 2021, for fishes, Frost 2020, Uetz et al. 2020, and Speybroeck et al. 2020 for amphibians and reptiles - except as otherwise stated.

\section{Results}

Supraclass Pisces

Class Actinopteri

Ord. Acipenseriformes

Fam. Polyodontidae

Polyodon spathula (Walbaum, 1792). Common name(s): English: Paddlefish, Mississippi Paddlefish (Froese and Pauly 2019); Romanian: "pește spatulă"2 (Iacob and Petrescu-Mag 2008). The species is native to North America (Froese and Pauly 2019). It was introduced in aquaculture starting with 1992 (at Nucet fish farms, Dâmbovița county), it was successfully reproduced and then populated into some lakes along the Argeș river (Simeanu et al. 2015). Escapes from farms (probably both Romanian and Bulgarian) have led to specimens being found in the Argeș ("Grigore Antipa" National Museum of Natural History collection) and the Danube (Simonović et al. 2006; Bănăduc et al. 2014). These are most likely not reproducing (Nalbant 2003; Lenhardt et al. 2011), though some juveniles (which may have escaped from farms) were found in the lower Danube river (Jarić et al. 2019). There is little information on the potential of Polyodon for impact upon native species; still, as there is no firm evidence for its reproduction in natural waters anywhere it was stocked, it is considered of low risk of becoming invasive (Jarić et al. 2019).

2 We give between quotation marks such Romanian names that we consider artificial and/or (from a Romanian language point of view) unhappy translations of English common names. 
Fam. Acipenseridae

Acipenser baerii Brandt, 1860. Common name(s): English: Siberian Sturgeon (Froese and Pauly 2019); Romanian: sturion siberian (CE regulation no. 506/2008), nisetru siberian (WWF Internațional/Programul Dunăre-Carpați 2014). The species is native to Siberia (Froese and Pauly 2019). This species was introduced in aquaculture in Romania in the early 2000s (Williot and Chebanov 2018). There are no records of this species escaping from Romanian farms so far, but upon floods in 2008 numerous specimens from Ukrainian farms have reached into the Prut river and the species was found down to the Stânca-Costești reservoir, on the Romanian-Moldavian border, in 2008-2009 (Khudyi and Khuda 2013) - therefore, A. baerii can be said to have reached free Romanian waters. However, it was not caught in that lake in a 2014 study, but neither was the native sterlet (Acipenser ruthenus), known to be present from fishermen's reports (Bulat et al. 2016). A. baerii has also escaped in the Middle Danube region, being present in free waters of Hungary (Weiperth et al. 2013) and has already hybridized with the native species Acipenser ruthenus (Ludwig et al. 2009). Hybrids of Acipenser baerii and Acipenser gueldenstaedtii are also kept in aquaculture in Romania (Popa et al. 2017).

\section{Ord. Cypriniformes}

Fam. Cyprinidae

\section{Subfam. Cyprininae}

Carassius (auratus) auratus (Linnaeus, 1758). Common name(s): English: Goldfish (Froese and Pauly 2019); Romanian: caras roșu (Bănărescu 1964). The species is native to Eastern Asia (Froese and Pauly 2019). Goldfishes were introduced into ornamental and angling fishponds, sometimes escaping into rivers such as the Jiu (Bănărescu 1964; Oțel 2019). The "goldfish" is distinct from the "gibel carp" or "Prussian carp", Carassius (auratus) gibelio (Bloch, 1782) ${ }^{3}$. The former is an Asian

3 Rylková et al. 2013, Oțel 2019 and Fricke et al. 2021 (among others) consider gibelio a valid species. However, it appears to be a (mostly) polyploid, alternately sexual and clonal (gynogenetic) form of $C$. auratus (Xiao et al. 2011; Luo et al. 2014; Li et al. 2018). Morphologically gibelio and auratus overlap (Oțel 2019), and gibelio appears to be but one of many recurrently/fluctuatingly polyploid auratus strains (Qin et al. 2016; Liu et al. 2017). Apparently sexual individuals of all forms of the C. auratus group (auratus, gibelio and even the Japanese cuvieri) interbreed without ill effects (Xiao et al. 2011; Kokodiy 2018; Liu et al. 2019; Mezhzherin et al. 2020) and the sex determinism is partly genetic and partly temperature dependent ( $\mathrm{Li}$ et al. 2018); this and parasite resistance dynamics (Pakosta et al. 2018) determine frequent reversal of gynogenetic condition towards the sexual one (Xiao et al. 2011; Rylková et al. 2013; Luo et al. 2014; Li et al. 2018; Przybył et al. 2020). Therefore, gibelio is best considered a subspecies/form of $C$. auratus, wider spread across Eurasia (including Eastern Europe) than the typical C. a. auratus (native to Eastern Asia). Sexual (and even gynogenetic) forms of this 
fish, the latter (despite being frequently treated as alien, e.g. Bănărescu 1964; Iacob and Petrescu-Mag 2008) is arguably native not only in Siberia but also in Central and Eastern Europe (see, e.g., Rylková et al. 2013; Fricke et al. 2021) including the Romanian Danube and its large tributaries (as convincingly argued on basis of historical but accurate information by Oțel 2019). The expansion of the gibel carp to the detriment of the crucian carp, Carassius carassius, appears to be primarily a consequence of anthropogenic ecological change favouring the first species (shift from clear to turbid water, see Năvodaru et al. 2002) and but secondarily the result of competition (following artificial translocations of $C$. (a.) gibelio, as stated by some authors - e.g. Bănărescu 1993; Bănărescu 2005). As for the goldfish, the impact of its introduction is unclear for now; it might hybridize with the gibel carp (Oțel, pers. comm.), which is to be expected given their conspecific condition.

\section{Subfam. Smiliogastrinae}

Pethia conchonius (Hamilton, 1822). Common name(s): English: Rosy Barb (Froese and Pauly 2019). The species is native to South Asia (Froese and Pauly 2019). Temporarily introduced to a small basin in the Botanical Garden in Bucharest by aquarists (Gavriloaie 2008); they reproduced during summer but died with the cold of late autumn (Iftime and Iftime, pers. obs., 2001).

Pethia ticto (Hamilton, 1822). Common name(s): English: Ticto Barb (Froese and Pauly 2019). The species is native to South and South-East Asia (Froese and Pauly 2019). Temporarily introduced to the same small basin in Bucharest by aquarists (Gavriloaie 2008); they reproduced during summer but died with the cold of late autumn (Iftime and Iftime, pers. obs., 2001).

Fam. Xenocyprididae

Hypophthalmichthys molitrix (Valenciennes, 1844). Common name(s): English: Silver Carp (Froese and Pauly 2019); Romanian: sânger, hipo, crap chinezesc (Oțel 2007). The species is native to Eastern Asia (Froese and Pauly 2019). This species was introduced together with other "Asiatic cyprinids" (Hypophthalmichthys nobilis, Ctenopharyngodon idella, Mylopharyngodon piceus, Parabramis pekinensis, Megalobrama terminalis) in 1960-1962 at the fish farms Nucet, Caraorman (Tulcea county) and Cefa (Bihor county); it was also deliberately populated in lakes, fishponds and reservoirs (Bușniță 1964; Manea 1985; Oțel 2007; Gavriloaie et al. 2015). Apparently numerous specimens escaped from culture in the 1970 s, aided by

species do interbreed with C. carassius, but the scarcity of such hybrids (Mezhzherin et al. 2017), their growth rate, initially high supposedely due to heterosis, but afterwards much decreased (Kokodiy 2018) and their ploidy aberrations (Knytl et al. 2018) would indicate that $C$. carassius is a distinct species from C. auratus/gibelio. 
flooding (Ciolac 2004). It has acclimated and reproduces freely in natural waters in the Danube and its Delta (Jankovic 1998; Staraș and Oțel 1999; Nalbant 2003; Ciolac 2004; Oțel 2007; Iacob and Petrescu-Mag 2008; Lenhardt et al. 2011; Zorić et al. 2014; Gavriloaie et al. 2015), though there are opinions that it cannot as yet reproduce in Bulgarian waters, including the Danube (Yankova 2016). Reproduction is dependent upon "long unregulated water courses in which the pelagic eggs can incubate" (Copp et al. 2005), conditions that are only met in some areas and periods (Staraș and Oțel 1999; Oțel 2007), therefore reproduction, while probably sufficient to propagate the Danube population independently of re-stocking from farms, is limited. The species is widespread in the Danube and Delta, but also found in most large rivers, though it does not reproduce there (Oțel 2007). It was particularly abundant during the mid-to-late 1990s in the lower Danube and its Delta but has declined later (Ciolac 2004; Oțel 2007). Its spread appears to have coincided with the anthropogenic (but independent from alien species introductions) shift from clear water to turbid water in most of the lower Danube and Delta (Năvodaru et al. 2002; Copp et al. 2005). Thus, this species, a phytoplankton filter-feeder, likely profited from the increased nutrient load (and associated algal blooming), hence probably its abundance and later decline. Some studies claim that $H$. molitrix can compete with native planktivorous species, e.g. in lake Balaton (Boros et al. 2015), where, however, the stock is derived from farming, not reproducing in free waters (Vitál et al. 2017). Other authors estimate that its impact upon native species is limited, as it has reached an ecological equilibrium state (Lenhardt et al. 2011) or is insufficiently known (Soes et al. 2011; Povž 2017), as is its capacity of controlling algal blooms (Vörös 2000; Oțel 2007). The introduction and transport of $H$. molitrix and other Asian carps has probably contributed to the establishment of the Asian bivalve Sinanodonta woodiana in Romania and Europe (Popa et al. 2011; Konečny et al. 2018). It has been conjectured that H. molitrix, may, through spread of $S$. woodiana, negatively impact the native species Rhodeus amarus (Soes et al. 2011). However, the impact of $S$. woodiana upon $R$. amarus was estimated as ranging "from almost neutral to highly negative" (Konečny et al. 2018, and literature quoted therein), with Danubian R. amarus in the "almost neutral" part of the spectrum (Reichard et al. 2015), all the more that in Romania R. amarus remains relatively abundant (Oțel 2007).Therefore, and inasmuch as its free-range reproduction is probably discontinuous and its free-ranging stock has apparently declined after a peak, its actual impact as an established non-native species in Romania is likelier to be limited than otherwise.

Hypophthalmichthys (Aristichthys) nobilis (Richardson, 1845). Common name(s): English: Bighead Carp (Froese and Pauly 2019); Romanian: novac, crap chinezesc (Oțel 2007). The species is native to Eastern Asia (Froese and Pauly 2019). It was introduced - and has escaped - together with other Asiatic cyprinids, but its freerange reproduction is doubtful (see discussion at Jankovic 1998; Nalbant 2003; Ciolac 2004; Oțel 2007; Iacob and Petrescu-Mag 2008; Zorić et al. 2014; Gavriloaie et al. 2015; Yankova 2016). It is far rarer in the Danube and Delta than H. molitrix (Oțel 2007). 
It is a zooplankton filter-feeder (Oțel 2007). The impact could be similar to that of $H$. molitrix, but proportional to the lesser abundance of $H$. nobilis; some authors even comment about a mainly positive effect of $H$. nobilis upon native fishes (see Lenhardt et al. 2011 and literature quoted). Hybrids between the two Hypophthalmichthys are known, e. g. in Hungary (Boros et al. 2015).

Ochetobius elongatus (Kner, 1867). Common name(s): none in either English or Romanian (Froese and Pauly 2019). The species is native to Eastern Asia (Froese and Pauly 2019). It has been introduced unwittingly together with the other Asiatic cyprinids; it lived in fishponds but did not escape to free waters and has doubtlessly been eliminated along time (Bușniță 1964).

Xenocypris macrolepis Bleeker, 1871. Common name(s): English: Yellowfin (Froese and Pauly 2019). The species is native to Eastern Asia (Froese and Pauly 2019). Same introduction history as above (Bușniță 1964).

Pseudobrama simoni (Bleeker, 1864). Common name(s): none in either English or Romanian (Froese and Pauly 2019). The species is native to Eastern Asia (Froese and Pauly 2019). Same introduction history as above (Bușniță 1964).

(Subfam. Squaliobarbinae)

Ctenopharyngodon idella (Valenciennes, 1844). Common name(s): English: Grass Carp (Froese and Pauly 2019); Romanian: cosaș, cteno, amur alb, crap chinezesc (Oțel 2007). The species is native to Eastern Asia (Froese and Pauly 2019). Its introduction history is identical to that of Hypophthalmichthys. Its free-range reproduction is doubtful, or at least is discontinuous, more so than for H. molitrix (see discussion at Jankovic 1998; Nalbant 2003; Ciolac 2004; Oțel 2007; Iacob and Petrescu-Mag, 2008; Lenhardt et al. 2011; Zorić et al. 2014; Gavriloaie et al. 2015; Yankova 2016). While some authors were optimistic as to $C$. idella not having a significant impact upon native species (e. g. Van Zon 1977), others observed it caused disruptions, especially through consumption of aquatic macrophytes, reducing the spawning options of phytophylous fishes (Lehtonen 2002) such as Tinca tinca (Lenhardt et al. 2011, and literature quoted therein). However, in Romania the decline of Tinca and its subsequent recovery correlate with the dynamics of anthropogenic eutrophication (Oțel 2007). Outside of intensive stocking, C. idella is not numerous (Oțel 2007), probably not enough to create a significant impact.

Mylopharyngodon piceus (Richardson, 1846). Common name(s): English: Black Carp (Froese and Pauly 2019); Romanian: scoicar (Oțel 2007). The species is native to Eastern Asia (Froese and Pauly 2019). In Romania it was introduced in aquaculture/ fishponds together with other Asiatic cyprinids (with the intent of making use of the abundant mollusk resource, as it is an eater of mollusks - Manea,1985) but it does not 
reproduce unassisted here and only persists in culture, in small numbers (Iacob and Petrescu-Mag 2008; Gavriloaie et al. 2015). Apparently, it occurs in the Hungarian stretch of the Crișul Repede/Sebes Körös river (Telcean et al. 2005; Telcean and Cupșa 2009), however, it is unclear whether it reproduces there.

Squaliobarbus curriculus (Richardson, 1846). Common name(s): English: Barbel Chub (Froese and Pauly 2019). The species is native to Eastern Asia (Froese and Pauly 2019). It has been introduced unwittingly together with the other Asiatic cyprinids; it lived in fishponds but did not escape to free waters and has doubtlessly been eliminated along time (Buşniță 1964).

(Subfam. Cultrinae)

Parabramis pekinensis (Basilewsky, 1855). Common name(s): English: White Amur Bream (Froese and Pauly 2019); Romanian: plătică albă chinezească (Iacob and Petrescu-Mag 2008). The species is native to Eastern Asia (Froese and Pauly 2019). It was introduced in aquaculture/fishponds together with other Asiatic cyprinids, but apparently the attempt was only transiently successful, and nowadays the species is no longer present in Romania (Bușniță 1964; Iacob and Petrescu-Mag 2008; Gavriloaie et al. 2015).

Megalobrama terminalis (Richardson, 1846). Common name(s): English: Black Amur Bream (Froese and Pauly 2019); Romanian: plătică neagră chinezească (Iacob and Petrescu-Mag 2008). The species is native to Eastern Asia (Froese and Pauly 2019). Same introduction history as P. pekinensis (Bușniță 1964; Iacob and Petrescu-Mag 2008; Gavriloaie et al. 2015).

Hemiculter leucisculus (Basilewsky, 1855). Common name(s): English: Sharpbelly (Froese and Pauly 2019). The species is native to Eastern Asia (Froese and Pauly 2019). It has been introduced unwittingly together with the other Asiatic cyprinids; it lived in fishponds but did not escape to free waters and has doubtlessly been eliminated along time (Bușniță 1964).

Toxabramis argentifer Abbott, 1901. Common name(s): none in either English or Romanian (Froese and Pauly 2019). The species is native to Eastern Asia (Froese and Pauly 2019). Same introduction history as H. leucisculus (Bănărescu 1963; Bușniță 1964).

Pseudolaubuca engraulis (Nichols, 1925). Common name(s): none in either English or Romanian (Froese and Pauly 2019). The species is native to Eastern Asia (Froese and Pauly 2019). Same introduction history as above (Bușniță 1964). 
Fam. Gobionidae

Pseudorasbora parva (Temminck et Schlegel, 1846). Common name(s): English: Stone Moroko (Froese and Pauly 2019); Romanian: murgoi bălțat (Oțel 2007). The species is native to Eastern Asia (Froese and Pauly 2019). It has been introduced unwittingly together with the other Asiatic cyprinids, and has escaped from the fishponds spreading through the Danube watershed practically all over the country, in the plains and lower hills, occasionally penetrating the sub-montane areas. It was also vehiculated by fishermen as bait (Bușniță 1964; Bănărescu 1964; Bănărescu et al. 1999; Oțel 2007; Iacob and Petrescu-Mag 2008; Gavriloaie et al. 2015; Telcean et al. 2015). According to some opinions it did not cause a decline in any native fish species (Bănărescu 1993); others claim a negative impact upon native fishes and cyprinid aquaculture (e.g. Giurcă and Angelescu 1971; Oțel 2007). Foreign free-range studies are not unanimous as to the impact upon native species abundance, through competition and/or disease vehiculation (see, e.g., Rosecchi et al. 1993; Carpentier et al. 2007; Gozlan et al. 2010; Didenko and Kruzhylina 2015; Povž 2017; Lojkásek and Lusk 2018; Spikmans et al. 2020). This species can feed upon the mucus of larger fish species, causing wounds and infections (Oțel 2007). P. parva preys upon eggs and larvae of amphibians when introduced to ponds where these reproduce, but so do many native fishes (Hartel et al. 2007). Therefore, non-native fishes are more of a threat for native amphibians than native fishes only inasmuch they are likelier to penetrate habitats previously devoid of fish, where non-fish-tolerating amphibians do reproduce, or inasmuch as they are more effective predators of amphibians than native species and it is unclear whether $P$. parva meets such criteria. Occasionally some amphibians - i. e. Triturus cristatus - can turn the tables and feed upon the introduced P. parva, if only on dead ones (Iftime and Iftime 2011).

Fam. Catostomidae

Subfam. Ictiobinae

Ictiobus niger (Rafinesque, 1819). Common name(s): English: Black Buffalo (Froese and Pauly 2019); Romanian: buffalo negru (Iacob and Petrescu-Mag 2008). The species is native to North America (Froese and Pauly 2019). It was introduced in 1978-1980 in aquaculture at Nucet and in the Danube Delta, together with other "buffalofish" species (Ictiobus bubalus, I. cyprinellus) (Gavriloaie and Berkesy 2013; Oțel, V., pers. comm.). In the Danube Delta the farmed stock was lost to disease (Oțel, V., pers. comm.). Apparently, it is still maintained in Romanian fishponds (Gavriloaie and Berkesy 2013).

Ictiobus bubalus (Rafinesque, 1818). Common name(s): English: Smallmouth Buffalo (Froese and Pauly 2019); Romanian: buffalo cu gura mică (Iacob and PetrescuMag, 2008). The species is native to North America (Froese and Pauly 2019). The 
introduction history is the same as for I. niger (Gavriloaie and Berkesy 2013; Oțel, V., pers. comm.). Apparently no longer present in Romania (Gavriloaie and Berkesy 2013). However, it occurs in the Hungarian stretch of the Crișul Repede/Sebes Körös river (Telcean et al. 2005; Telcean and Cupșa 2009).

Ictiobus cyprinellus (Valenciennes, 1844). Common name(s): English: Bigmouth Buffalo (Froese and Pauly 2019); Romanian: buffalo cu gura mare (Iacob and Petrescu-Mag, 2008). The species is native to North America (Froese and Pauly 2019). The introduction history is the same as for I. niger and I. bubalus (Gavriloaie and Berkesy 2013; Oțel, V., pers. comm.). Considered no longer present in Romania (Gavriloaie and Berkesy 2013) but recently there are mentions of its introduction (as bigmouth buffalo) to at least one fishery (Iazul Bârca 2020).

Ord. Characiformes

Fam. Serrasalmidae

Piaractus brachypomus (Cuvier, 1818). Common name(s): English: Pacu, Pirapitinga (Froese and Pauly 2019); Romanian: pacu (GherlaInfo 2019a). The species is native to South America (Froese and Pauly 2019). Specimens were recently (2017-2019) captured in the Danube and Lake Firiza, Maramureș county, as well as in the Someș, at Gherla; they were at first taken for the similar-looking, feared piranha fishes, from the same family (Tarnovschi 2019; GherlaInfo 2019a). They are probably released from aquaria as has happened in other European countries (Piria et al. 2017) - at least in one case this was confirmed (GherlaInfo 2019a).

\section{Ord. Siluriformes}

Fam. Ictaluridae

Ameiurus nebulosus (Lesueur, 1819). Common name(s): English: Brown Bullhead (Froese and Pauly 2019); Romanian: somn pitic, somn american (Wilhelm 2013; Froese and Pauly 2019). The species is native to North America (Froese and Pauly 2019). It was introduced in Lake St. Ana (Harghita county) in 1908, but also appeared in Romania through secondary dispersion from other European introductions, especially in the western-draining rivers (Tisa catchement, Timiș) but also in the lower Danube, Argeș watershed and the lakes in Bucharest (Bănărescu 1964; Ardelean and Bere, 2000; Stănescu and Gavriloaie 2011; Gavriloaie and Berkesy 2013; Wilhelm 2013; Iftime and Iftime, pers. obs., 2020 - Fig. 1; identification after the morphological criteria as given by Nowak et al. 2010, Rutyaková et al. 2012, and Wilhelm 2013). Romanian studies indicate that it has no negative impact upon native fishes, at least not through direct consumption (Gavriloaie and Berkesy 2013, and literature quoted therein). In neighbouring countries it has been repeatedly pointed as detrimental to 


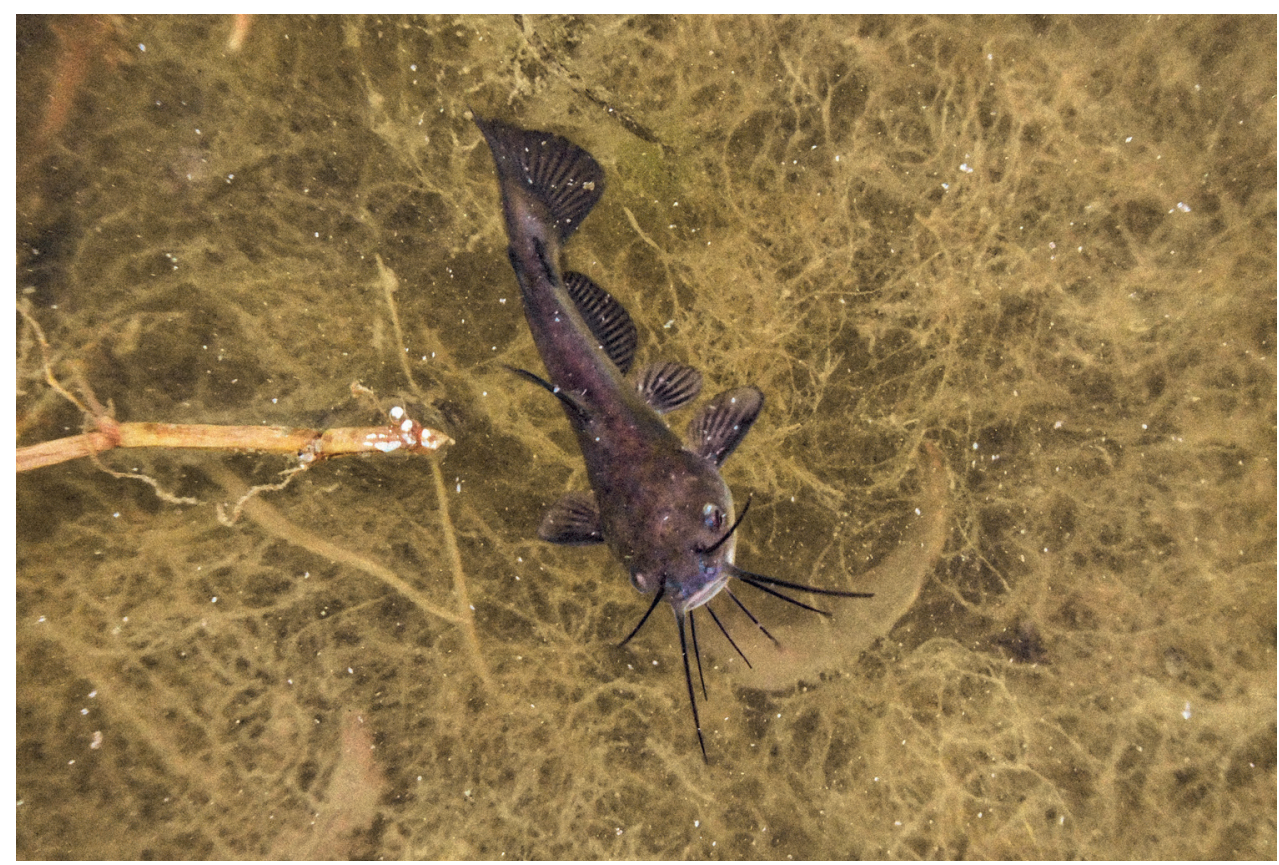

Figure 1. Ameiurus nebulosus, Bucharest, lake in National Stadium Park, 2020, photo O. Iftime.

other fishes (Lenhardt et al. 2011; Movchan et al. 2014, and literature quoted therein), though there are opinions that its impact is unknown (Povž 2017).

Ameiurus melas Rafinesque, 1820. Common name(s): English: Black Bullhead (Froese and Pauly 2019); Romanian: somn pitic negru (Wilhelm 2013; Froese and Pauly 2019). The species is native to North America (Froese and Pauly 2019). It appeared in Romanian waters in 1997 through secondary dispersion from other European introductions; it is mostly found in the Tisa catchment (Gavriloaie and Berkesy 2013; Telcean and Cupșa 2009; Păpuc et al. 2018; Wilhelm 2013) but also in the Danube (Popa et al. 2006) and Bucharest lakes (Iftime and Iftime, pers. obs., 2021 - Fig. 2; identification after the morphological criteria as given by Nowak et al. 2010, Rutyaková et al. 2012, and Wilhelm 2013). According to some studies it might displace A. nebulosus, at least partly (Wilhelm 2013; Movchan et al. 2014) but in Romania the two appear to coexist widely (Telcean and Cupșa 2009).

Ictalurus punctatus (Rafinesque, 1814). Common name(s): English: Channel Catfish (Froese and Pauly 2019); Romanian: "pește-pisică de canal" (Iacob and PetrescuMag 2008). The species is native to North America (Froese and Pauly 2019). It was introduced unsuccessfully in Nucet fishponds in 1978; re-introduced in 1981, it still persists in reduced number in the same fishponds (Gavriloaie and Berkesy 2013). It apparently occurs in the Prut river basin, probably including Romanian waters 


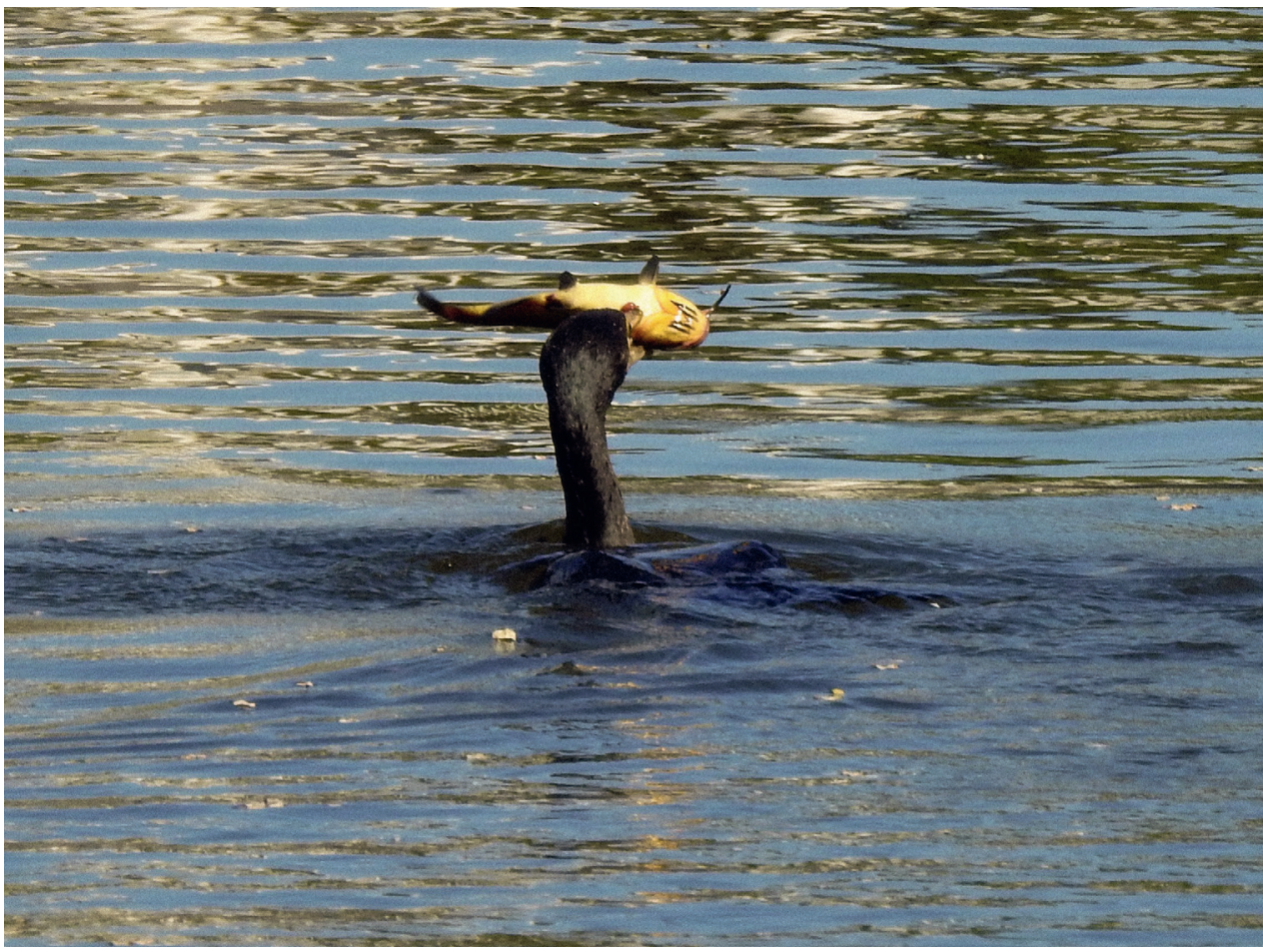

Figure 2. Ameiurus melas, Bucharest, lake in Bordei Park, caught by a cormorant, photo A. Iftime.

(Moshu et al. 2006); it is also found in the Hungarian stretch of the Crișul Repede/ Sebes Körös river, but not in the Romanian stretch (Telcean et al. 2005; Telcean and Cupșa 2009).

Fam. Clariidae

Clarias gariepinus Burchell, 1822. Common name(s): English: Sharptooth Catfish, North African Catfish (Froese and Pauly 2019); Romanian: somn african (Iacob and Petrescu-Mag, 2008). The species is native to Africa and the Near East (Froese and Pauly 2019). This species was introduced in aquaculture in Romania in 2002, together with Clarias gariepinus X Heterobranchus longifilis Valenciennes, 1840 hybrids (Iacob and Petrescu-Mag 2008), mostly making use of thermal waters (Dynavit Impex 2021; Oțel, V., pers. comm.). Nowadays C. gariepinus occurs in fishponds in the Crișul Repede/Sebes Körös river drainage; it was found in the Hungarian stretch of the same river, but not free-ranging in Romania (Telcean et al. 2005); it is doubtful whether it can survive overwinter (especially in harder winters) in European free waters (Piria et al. 2019). The similar, south-central African species Clarias ngamensis Castelnau, 1861 was published as a new introduction record after a single specimen was found dead at the edge of a lake in Bucharest, in November 2004 (Gavriloaie and 
Chișamera 2005). As the animal was not found alive and it is unclear how it ended up there, this being the first record for Europe (! - Iacob and Petrescu-Mag 2008) and C. ngamensis is not a widely-kept aquaculture species (Na-Nakorn and Brummett 2009), we express doubts that this species can be considered as introduced alive to any Romanian water; at best it could have been released from an aquarium and died of cold (Iacob and Petrescu-Mag 2008), but it may just as well have been discarded after purchase from a supermarket, as imported Clarias fishes were widely available as such at the time (Iftime and Iftime, pers. obs., 2004-2005).

\section{Ord. Salmoniformes}

Fam. Salmonidae

\section{Subfam. Coregoninae}

Coregonus (albula) ladogae (Pravdin, Golubev et Belyaeva, 1938). Common name(s): English: Vendace (for C. albula; C. (a.) ladogae has no specific common name) (Froese and Pauly 2019); Romanian: coregon mic (Bănărescu 1964). The species is native to Lake Ladoga, Russia (Froese and Pauly 2019). This species was introduced in 1956, together with C. maraenoides (at that time the introduced stock was labeled as $C$. albula ladogensis, a replacement subspecific name now considered unnecessary as the earlier ladogae was shown to be available; ladogae is now frequently considered a distinct species ${ }^{4}$ - Fricke et al. 2021, and literature quoted therein). These were first brought into aquaculture in the fish farms at Nucet and Tarcău (Neamț county) and then introduced into some lakes and reservoirs, including Lake Roșu, a natural dam lake in Harghita county, the alpine lake Călțun in Făgăraș mountains, and the reservoirs of Bicaz, Vidraru, Vidra (Lotru) and Făerag (Bănărescu 1964; Decei 1981; Manea 1985; Iacob and Petrescu-Mag 2008; Gavriloaie et al. 2015). A Coregonus species, possibly one of these two, was also introduced to Tarnița reservoir (Cluj county) but specimens were not available in 1992-1996 (Bănărescu et al. 1999). Some authors treat them as no longer spawning in free waters (Nalbant 2003), others consider their current fate unknown (Iacob and Petrescu-Mag 2008; Gavriloaie et al. 2015). The management plan of the Cheile Bicazului-Hășmaș National Park, which includes Lake Roșu, does not mention any Coregonus species being found in that waterbody (Romanian Environment Ministry 2016).

4 The genus Coregonus is notorious for difficult species delimitation. There are many ecological and geographical forms that are hard to distinguish from valid, reproductively separated species - see, e. g., Sendek 2004; Østbye et al. 2005; Hansen et al. 2008; Bhat et al. 2014. It appears that many "species" do not stand the criterion of reproductive incompatibility. However, pending precise data for the forms here discussed, we use the currently most widely admitted nomenclature, but with the caveat of possible subspecies/local form status. 
Coregonus (lavaretus) maraenoides (Polyakov, 1874). Common name(s): English: Peipsi Whitefish (Froese and Pauly 2019); Romanian: coregon (Bănărescu 1964). The species is native to Lake Peipus (Peipsi) and associated waters between Russia and Estonia (Froese and Pauly 2019). The introduction history is the same as for C. albula; at the time the introduced stock was labeled as C. lavaretus maraenoides (Bănărescu 1964; Decei 1981; Manea 1985; Iacob and Petrescu-Mag 2008; Gavriloaie et al. 2015), a subspecies now frequently treated as a valid species (Fricke et al. 2021). Like $C$. albula, it was not found in Lake Roșu during the elaboration of the management plan of the Cheile Bicazului-Hășmaș National Park (Romanian Environment Ministry 2016). However, some specimens of "Coregonus lavaretus" (probably of this C. (l.) maraenoides stock) were found in 2010 in the Vidraru reservoir (Argeș county) as per the data of the "Apele Române" (Romanian Waters) National Administration for 2010 (Csaba et al. 2011). The impact of such a population upon native fishes should be minimal, especially as they, if still present, are confined to one artificial lake. Coregonus maraena is mentioned in the DAISIE database as introduced to Romania (Roy et al. 2020); this unsourced mention was probably a confusion with C. (l.) maraenoides (Stănescu et al. 2020).

Coregonus peled (Gmelin, 1789). Common name(s): English: Peled (Froese and Pauly 2019), Romanian: coregon (Iacob and Petrescu-Mag 2008). The species is native to northern Russia (Froese and Pauly 2019). It was introduced to four alpine lakes in the Retezat massif (1967-1973) and subsequently in 1980 at the Podu Iloaiei fish farms (Iași county) (Decei 1981; Manea 1985; Cocoș 2007; Iacob and Petrescu-Mag 2008; Gavriloaie et al. 2015), and it is unclear whether it survived. At least some introductions were unsuccessful (Decei 1981; Demeter and Mori 2004; Cocoș 2007), and of the four lakes stocked with C. peled only one (Zănoaga) had recently any fish (Cogălniceanu et al. 2012). However, the lake was stocked with other species as well, and the survival of C. peled was considered unlikely even in 1981 (Decei 1981). C. peled was considered to have no negative impact in Serbia (Lenhardt et al. 2011). There is a negative correlation between fish stocking and the survival of crustacean and amphibian populations in Retezat alpine lakes, but this is valid for both native and non-native species (Demeter and Mori 2004; Cocoș 2007; Cogălniceanu et al. 2012). C. peled is doubtful to be a major factor in the local extinction of amphibian (meta) populations as it is mainly planktivorous (Malbrouck et al. 2005; Salonen and Mutenia 2007); translocations of the native Salmo trutta, which is known to occasionally eat amphibians (Bănărescu 1964) might have been more effective in that respect.

Subfam. Salmoninae

Oncorhynchus mykiss (Walbaum, 1792). Common name(s): English: Rainbow trout, Steelhead (Froese and Pauly 2019), Romanian: păstrăv curcubeu (Bănărescu 1964; Iacob and Petrescu-Mag 2008). The species is native to the Pacific coast of North America and to Kamchatka, as both freshwater and anadromous forms (Froese and 
Pauly 2019). It was introduced in Romania around 1885, in specialized trout farms (Bănărescu 1964; Manea 1985; Iacob and Petrescu-Mag 2008; Gavriloaie and Berkesy 2013). It has been released in various montane rivers and lakes (Bănărescu 1964; Decei 1981); however, despite repeated and massive stocking and escapes from farms, only one population in a stream in Maramureș county appears to be successfully reproducing (Ardelean and Beres 2000; Iacob and Petrescu-Mag 2008; Gavriloaie and Berkesy 2013). Whatever ecological impact it has must therefore be extremely limited; apparently the large-scale release of (eventually non-reproducing) individuals did not cause a reduction in native species (Bănărescu 1993).

Salvelinus fontinalis (Mitchill, 1814). Common name(s): English: Brook trout, Brook Char (Froese and Pauly 2019), Romanian: păstrăv fântânel (Bănăresc, 1964; Iacob and Petrescu-Mag 2008). The species is native to North America (Froese and Pauly 2019). It was introduced in Romania in 1900-1906 (Manea 1985; Iacob and Petrescu-Mag 2008), being bred in fish farms (Nistor et al. 2012) but also stocked into upper reaches of mountain brooks, upstream from the range of native salmonids (Bănărescu 1964; Manea 1985) or into alpine lakes (Decei 1981). It survives in small numbers in some locations (Iacob and Petrescu-Mag 2008; Dudu et al. 2010; Gavriloaie and Berkesy 2013; Bănăduc et al. 2013; Imecs et al. 2014; Imecs and Nagy 2016). Apparently, it has no negative impact upon native salmonids (Bănărescu 1964; Bănărescu 1993; Gavriloaie and Berkesy 2013).

Salvelinus alpinus (Linnaeus, 1758). Common name(s): English: Arctic Char (Froese and Pauly 2019), Romanian: păstrăv arctic (Sava et al. 2012). The species is native to northern areas of Eurasia and North America (Froese and Pauly 2019). It was recently introduced in Romania in specialized trout farms, in Bucegi and Bihor counties (Sava et al. 2012). So far there are no indications of either escape or release into natural waters.

\section{Ord. Gobiiformes}

\section{Fam. Odontobutidae}

Perccottus glenii Dybowski, 1877. Common name(s): English: Chinese Sleeper, Amur sleeper (Froese and Pauly 2019), Romanian: "guvid adormit" (Iacob and Petrescu-Mag 2008). The species is native to Eastern Asia (Froese and Pauly 2019). This species has expanded into Romania from introductions in western Ukraine in the late 1960s (Reshetnikov 2013); the first Romanian record was in 2001 (Nalbant 2003; Nalbant et al. 2004). Subsequently it has spread throughout the Tisa catchment, the Timiş and Aranca, the Siret and Prut, the Balasan, the Danube and most of the Danube Delta (Năstase 2007; Reshetnikov 2013; Ureche and Ureche 2016; Covaciu-Marcov et al. 2017a; Covaciu-Marcov et al. 2017 b; Năstase et al. 2019, and literature quoted therein). It was recently found in the Black Sea as well, at the Ukrainian coast, 
suggesting a higher tolerance for salinity (and capacity for spreading) than previously believed (Kvach et al. 2021). It appears to be quite damaging to amphibian populations and even to some fishes (Reshetnikov 2013, and literature quoted therein); in Romania it was found to feed on newts, namely on Lissotriton vulgaris (Telcean and CicortLucaciu 2016), although it can coexist with this species, probably on a short term, before it eliminates it (Covaciu-Marcov et al. 2018). It presents a more severe threat than other introduced fishes as it can induce local extinctions of Triturus dobrogicus (Reshetnikov 2013) a species which otherwise is, unlike other European large newts, generally tolerant of fishes in its reproduction waterbodies (Arntzen and Wallis 1999).

Ord. Anabantiformes

Fam. Osphromenidae

Subfam. Macropodusinae

Macropodus opercularis (Linnaeus, 1758). Common name(s): English: Paradisefish (Froese and Pauly 2019), Romanian: pește paradis (Iacob and Petrescu-Mag 2008). The species is native to Eastern Asia (Froese and Pauly 2019). It is found in thermal waters at Băile Felix (Bihor county), probably as a release from aquaria, date unknown (Iacob and Petrescu-Mag 2008). The quoted authors stated that the species did not adapt very well to the new conditions and was reproducing poorly, suffering from the effects of the cold air (Iacob and Petrescu-Mag 2008). It was also found in one of the thermal lakes on the course of the thermal brook Pețea, close to Băile Felix, Bihor county (Iacob and Petrescu-Mag 2008; Gavriloaie et al. 2010); here the species probably died out with the massive dessication, brought about by the excessive diverting of thermal water, that devastated the native species in Pețea in 2012-2014 (Müller et al. 2018). Still, we have found specimens persisting in some small basins in one public park in Băile Felix through 2012-2015 (Iftime and Iftime, pers. obs.).

Betta splendens Regan, 1810. Common name(s): English: Siamese Fighting Fish (Froese and Pauly 2019), Romanian: pește luptător (Lozinsky, 2009). The species is native to South-East Asia (Froese and Pauly 2019). It was supposed to be present (but not actually found) as an introduction in one of the thermal lakes on the course of the thermal brook Pețea, close to Băile Felix, Bihor county (Lozinsky 2009). Other authors state that it was released frequently there, but doubt its overwinter persistence (Gavriloaie et al. 2010; Gavriloaie and Berkesy 2010). The grounds for surmising its introduction are unclear, since the species was not actually found (Lozinsky 2009; Gavriloaie et al. 2010); maybe the authors had knowledge of releases from the aquarists' community. Whatever the situation, even if it was present it could not have persisted after the dessication (Müller et al. 2018). 
Subfam. Trichogastrinae

Trichopodus trichopterus (Pallas, 1770). Common name(s): English: Threespot Gourami (Froese and Pauly 2019), Romanian: gurami (Iacob and Petrescu-Mag 2008). The species is native to South-East Asia (Froese and Pauly 2019). It is found in thermal waters at Băile Felix (Bihor county), probably as a release from aquaria, date unknown (Iacob and Petrescu-Mag 2008). The species is probably reproducing there, specimens from Băile Felix apparently being crosses between two colour forms commonly bred in aquaria (Iacob and Petrescu-Mag 2008). We have found them persisting through 2012-2015 (Iftime and Iftime, pers. obs.). It was also found in one of the thermal lakes on the course of the thermal brook Pețea, close to Băile Felix, Bihor county (Gavriloaie et al. 2010), but it probably perished with the massive dessication (Müller et al. 2018).

\section{Ord. Cichliformes}

Fam. Cichlidae

Subfam. Pseudocrenilabrinae

Oreochromis niloticus (Linnaeus, 1758). Common name(s): English: Nile Tilapia (Froese and Pauly 2019), Romanian: tilapia de Nil (Iacob and Petrescu-Mag 2008). The species is native to Africa from the Nile and Senegal to lake Tanganyika, and also to Israel (Froese and Pauly 2019). It was introduced in covered-basin aquaculture in Romania, together with O. mossambicus (Peters, 1852) (Iacob and Petrescu-Mag 2008); the authors consider that no Oreochromis can stand through the Romanian winters in open waterbodies (Iacob and Petrescu-Mag 2008). However, there are mentions of O. niloticus in the Hungarian stretch of the Crișul Repede/Sebes Körös river (Telcean et al. 2005; Telcean and Cupșa 2009), without indications of overwinter survival or otherwise. Also, there are introduced populations in the Balkans, but these generally take advantage of thermal waters (Piria et al. 2017).

Two more species of this family were tentatively identified by us in a basin in Bucharest:

Chindongo demasoni (Konings, 1994) (or C. demasoni X Labidochromis caeruleus Fryer, 1956 hybrid). Common name(s): none in either English or Romanian (Froese and Pauly 2019). The species is native to Lake Malawi in Africa (Froese and Pauly 2019). Temporarily introduced from aquaria to the same small basin in Bucharest as the Pethia species mentioned above; in September 2019 they were present but did not survive (or were captured and rescued) as the basin was emptied for the cold season. They were few in numbers, with no signs of reproduction (Iftime and Iftime, pers. obs.). 
Lithochromis rufus Seehausen et Lippitsch, 1998. Common name(s): none in either English or Romanian (Froese and Pauly 2019). The species is native to Lake Victoria in Africa (Froese and Pauly 2019). Temporarily introduced from aquaria to the same small basin in Bucharest as the Pethia species and Chindongo; in September 2019 they were relatively numerous but did not survive (or were captured and rescued) as the basin was emptied for the cold season. There were no indications of reproduction (Iftime and Iftime, pers. obs - Fig. 3).

Ord. Cyprinodontiformes

Fam. Poecilidae

Subfam. Poeciliinae

Gambusia holbrooki Girard, 1859. Common name(s): English: Eastern Mosquitofish (Froese and Pauly 2019), Romanian: gambuzie (Bănărescu 1964; Froese and Pauly 2019). The species is native to North America (Froese and Pauly 2019). It was introduced in 1927-1930 (as G. affinis or G. affinis holbrooki) in order to consume

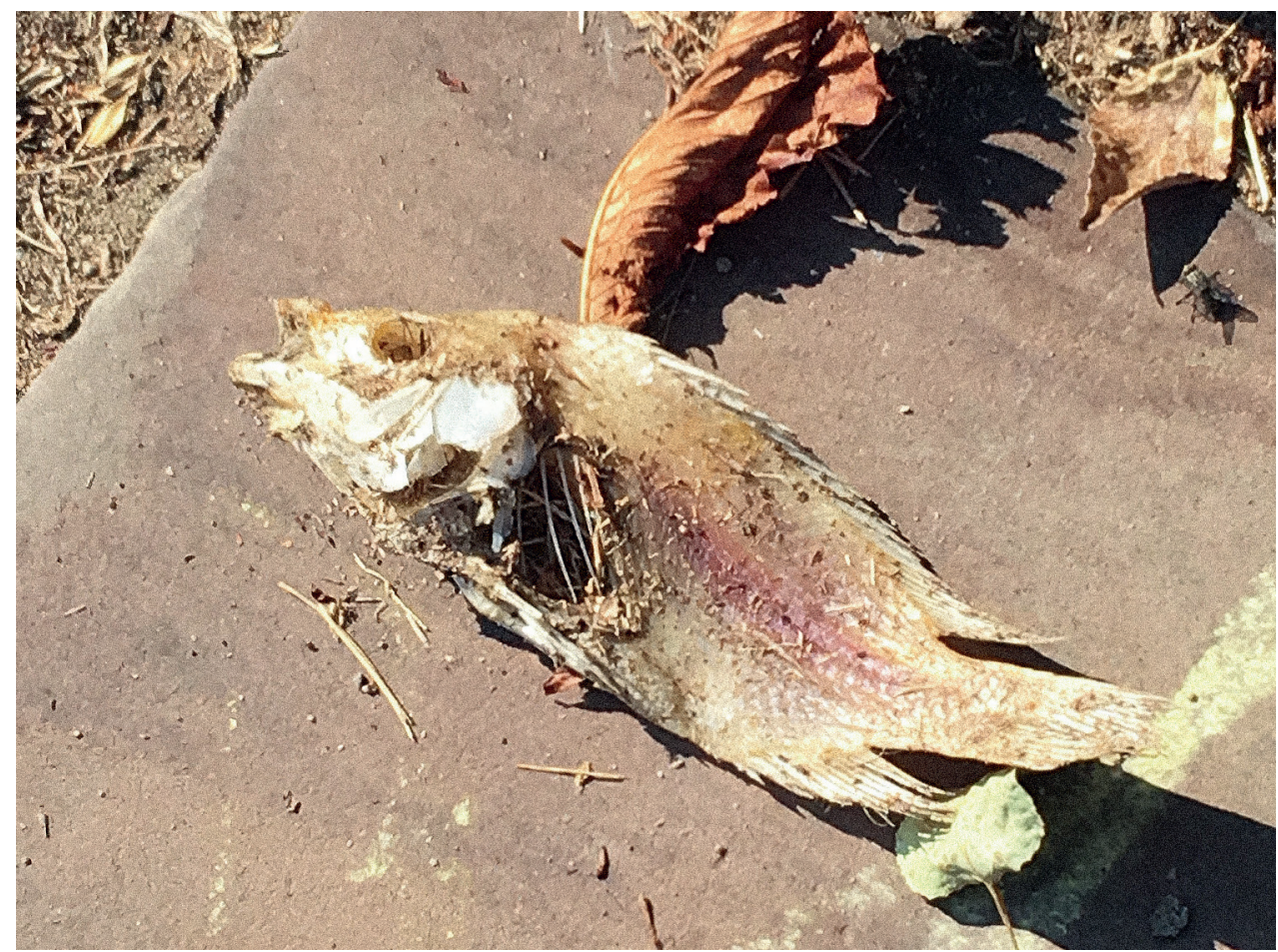

Figure 3. Lithochromis rufus (tentative identification) Bucharest, dead specimen near a pond in Botanical Garden (which also contained live specimens), 2019, photo O. Iftime. 
mosquito larvae and thus contribute to the control of malaria. The species was populated in Lake Mangalia, Constanța county (Bănărescu 1964) and/or Mlaștina Hergheliei/Balta Mangalia, where it survives (Popovici and Jianu 2006), also in other littoral lakes and in waterbodies in and nearby Bucharest and Oradea (Călinescu 1938; Bănărescu 1964; Papadopol et al. 2012; Gavriloaie and Berkesy 2013), is present in the lakes in Nicolae Romanescu Park in Craiova (Iftime and Iftime, pers. obs., 2020 - Fig. 4) and was even found in the main channel of the Danube (Polačik et al. 2008). However, at least in some places it did not persist; it was present in the late 1990s-early 2000s in the lake in Tineretului Park, Bucharest, but was no longer found by us in 2020-2021 (Iftime and Iftime, pers. obs., 1990-2021). It appears to be constrained by temperature to some extent, and is not tolerant of cold winters, long-term populations being thus mainly limited to Mediterranean and sub-Mediterranean areas, or urban settings with a favourable microclimate (see Landeka et al. 2015; Harka and Szepesi 2016); in Romania it appears, indeed, to have succeeded in the milder climate of the littoral, in thermal or thermal-influenced waters (e.g. at Mangalia - Popovici and Jianu 2006) and in some city parks. It is still anthropogenically bred and vehiculated, and reproduces well, even explosively on occasions (Papadopol et al. 2012). This species can have a significant detrimental impact upon native fish and amphibian species in some settings, e.g. in the Mediterranean area, as they are apparently capable of penetrating more amphibian breeding-grounds than native fishes (see, e.g., Iacob and Petrescu-Mag 2008; Landeka et al. 2015; Yankova 2016, and literature quoted therein; Vannini et al. 2018; Cabrera-Guzmán et al. 2019). However, in Romania the thermal constraint may have prevented such wide-scale penetration. There is, to our

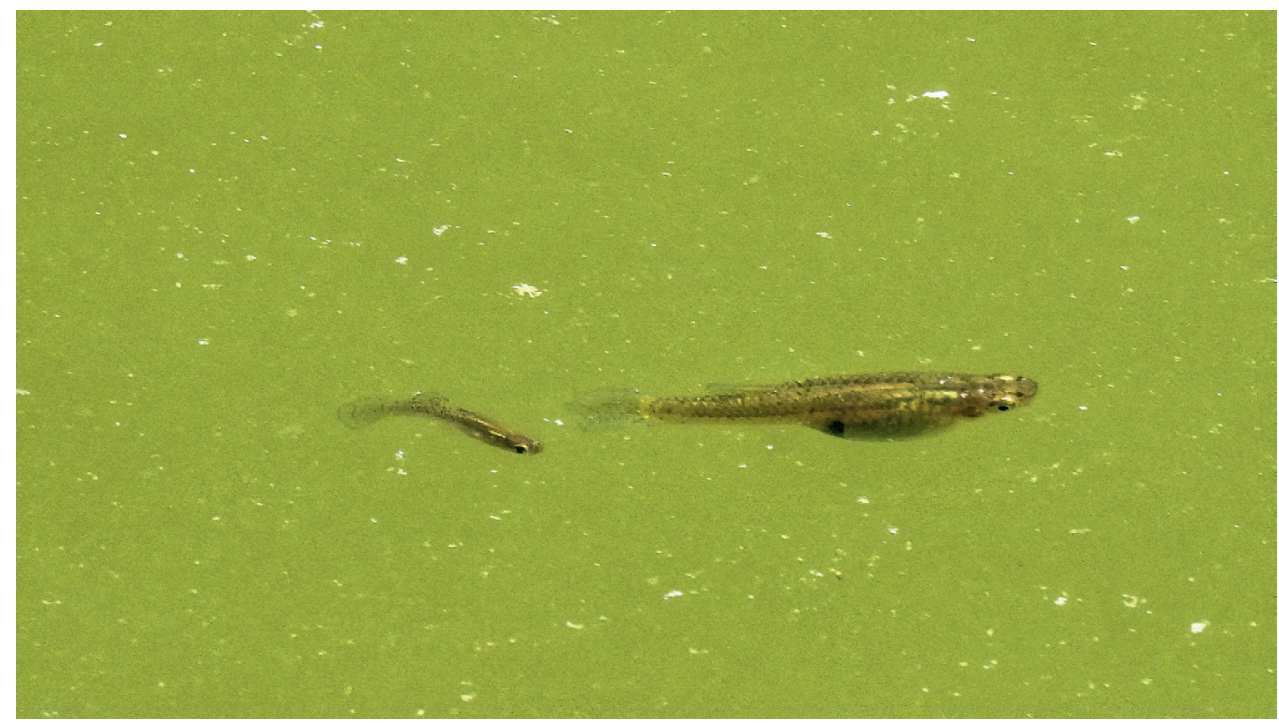

Figure 4. Gambusia holbrooki, male and female, Craiova, lake in N. Romanescu Park, 2020, photo A. Iftime. 
knowledge, no study on the impact of Gambusia in Romania, either in general or on amphibians (see Iacob and Petrescu-Mag 2008; Gavriloaie and Berkesy 2013); among amphibians, at least Pelophylax ridibundus is apparently unaffected by it, coexisting with Gambusia in reasonable numbers (Iftime and Iftime, pers. obs., 2020; cf. Vannini et al. 2018 noticing the same for Italian Pelophylax).

Poecilia reticulata Peters, 1859. Common name(s): English: Guppy (Froese and Pauly 2019), Romanian: guppy (Iacob and Petrescu-Mag, 2008). The species is native to South America (Froese and Pauly 2019). This common aquarium species was introduced into the thermal waters at Băile Felix and 1 Mai (Pețea) where it apparently reproduced (Iacob and Petrescu-Mag 2008; Gavriloaie et al. 2010; Gavriloaie and Berkesy 2013). However, the population in Pețea obviously perished due to the over-exploitation of thermal waters mentioned above, and in 2012-2015 we have not seen P. reticulata in the basins in Băile Felix either (Iftime and Iftime, pers. obs.). It was also transiently introduced in the same basin in Bucharest as Pethia and the above-mentioned cichlids, in 2000 and 2001 (Gavriloaie 2008) where it reproduced, but could not persist over the cold season (Iftime and Iftime, pers. obs., 2001).

Poecilia sphenops Valenciennes, 1846. Common name(s): English: Molly (Froese and Pauly 2019), Romanian: moly (Iacob and Petrescu-Mag 2008). The species is native to Central and South America (Froese and Pauly 2019). It was introduced from aquaria into the thermal waters at Băile Felix and 1 Mai (Pețea) where it apparently reproduced, but without reaching high densities (Iacob and Petrescu-Mag 2008; Gavriloaie et al. 2010; Gavriloaie and Berkesy 2013).

Xiphophorus helleri Heckel, 1848. Common name(s): English: Swordtail (Froese and Pauly 2019), Romanian: xipho (Iacob and Petrescu-Mag 2008). The species is native to Central America (Froese and Pauly 2019). It was introduced from aquaria into the thermal waters at Băile Felix and 1 Mai (Pețea) where it apparently reproduced (Iacob and Petrescu-Mag 2008; Gavriloaie et al. 2010; Gavriloaie and Berkesy 2013). There is no doubt that the population in Pețea perished (see above); in 2012-2015 we have not found the species in Băile Felix either (Iftime and Iftime, pers. obs.). It was also transiently introduced in the same basin in Bucharest as Pethia, cichlids and Poecilia reticulata in 2000 and 2001 (Gavriloaie 2008).

Xiphophorus maculatus (Günther, 1866). Common name(s): English: Platy, Southern Platyfish (Froese and Pauly 2019). The species is native to Central America (Froese and Pauly 2019). It was transiently introduced in one small waterbody in Bucharest in the same way as Pethia, cichlids and Poecilia reticulata (but the basin was different, albeit close by) in 2000 (Gavriloaie 2008). 


\section{Ord. Mugiliformes}

Fam. Mugilidae

Planiliza haematocheilus (Temminck et Schlegel, 1845). Common name(s): English: So-iuy Mullet (Oțel 2007; Froese and Pauly 2019), Romanian: chefal cu ochii roșii (Oțel 2007). The species is native to the Northwest Pacific and associated seas (Froese and Pauly 2019). It was introduced in 1972-1978 in the Sea of Azov and the Black Sea near Odessa; it has subsequently spread in all Romanian Black Sea waters as well as in the Sinoe lagoon (Oțel 2007). It reproduces freely (Oțel 2007). Its spread has coincided with, and may have caused, a reduction in the populations of native mugilid species (Yankova 2016, and literature quoted therein).

\section{Ord. Centrarchiformes}

\section{Fam. Centrarchidae}

Lepomis gibbosus (Linnaeus, 1758). Common name(s): English: Pumpkinseed (Oțel 2007; Froese and Pauly 2019), Romanian: biban soare, sorete, regină (Oțel 2007). The species is native to North America (Froese and Pauly 2019). It was introduced as an ornamental fish to Western and Central Europe (France and Germany) in the late XIXth century, whence it has spread eastward through the catchements of great rivers, notably the Danube. In Romania it seems to have appeared in 1918 (Iacob and Petrescu-Mag 2008; Gavriloaie and Berkesy 2013; Bănăduc et al. 2014, and literature quoted therein). It reproduces freely and has spread throughout the country, in most waters except those of the montane areas (Fig. 5), aided by fishermen and other enthusiasts who transported the species from one waterbody to another, as an ornamental fish or for the purpose of angling (Bănărescu 1964; Oțel 2007; Iacob and Petrescu-Mag 2008; Gavriloaie and Berkesy 2013). Some data from Romania suggest no negative influence of $L$. gibbosus on native species, at least not as regards the trophic spectrum (Bănăduc, unpubl., ap. Gavriloaie and Berkesy 2013), though others consider it damaging to native species (Bănărescu 1964) - but not a competitor of the native, ecologically similar Perca fluviatilis (Bănărescu 1993). Detrimental effects upon native species are reported in other countries, mostly in the Iberian peninsula (Yankova 2016, and literature quoted therein; Zięba et al. 2019, and literature quoted therein). It is among the species that are negatively associated with reproductive success in amphibians when introduced to ponds where these reproduce (Hartel et al. 2007).

Micropterus salmoides (Lacepède, 1802). Common name(s): English: Largemouth Black Bass, Romanian: biban cu gura mare (Froese and Pauly 2019). The species is native to North America (Froese and Pauly 2019). It was introduced sporadically for the purpose of angling, specimens being caught in the large, montane dam lakes 


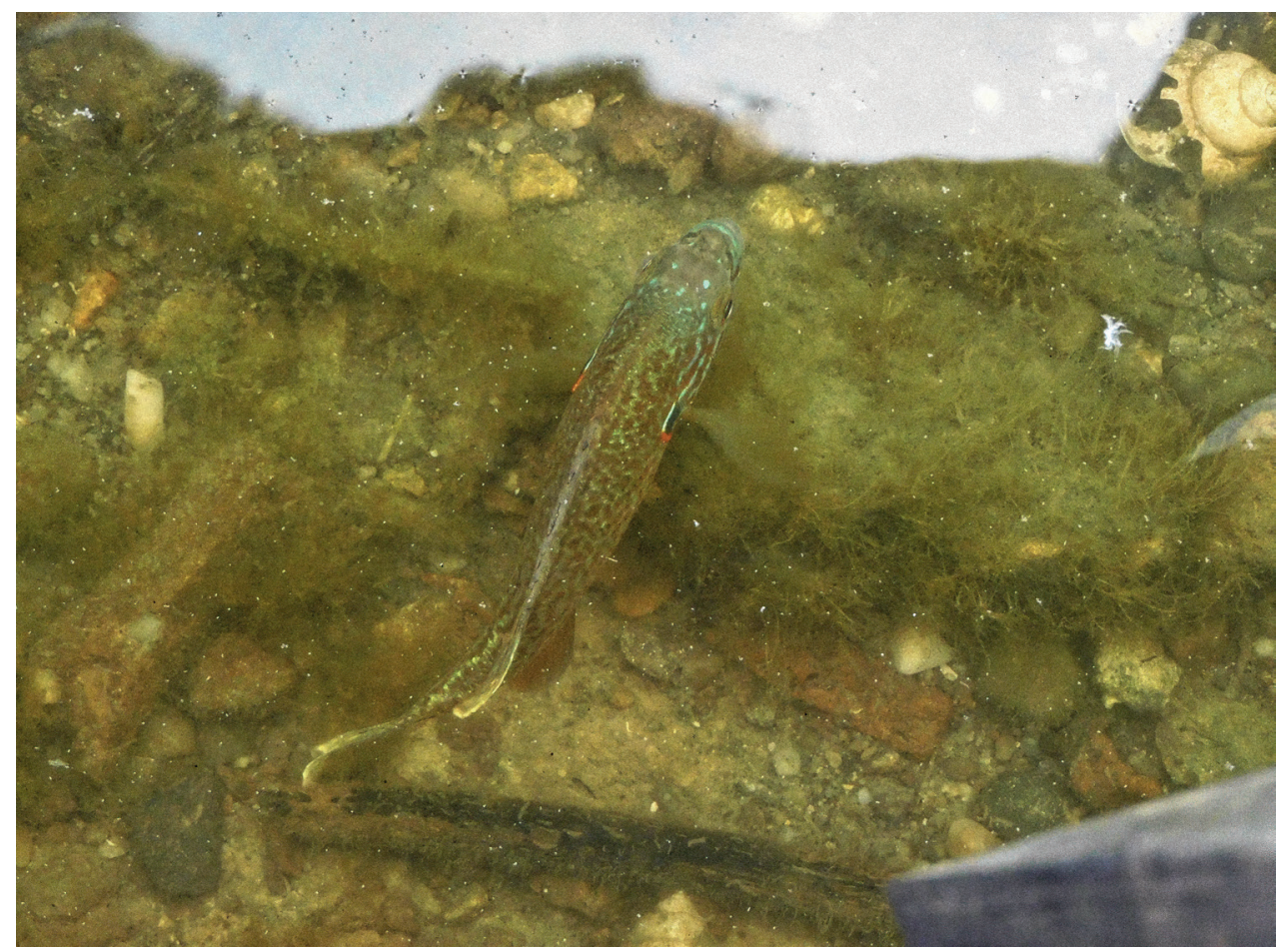

Figure 5. Lepomis gibbosus, Bucharest, lake in National Stadium Park, 2020, photo A. Iftime.

Colibița (Bistrița-Năsăud county) and Bicaz (Neamț county) (Froese and Pauly 2019); it was also populated near Bucharest, at Tâncăbești (Andy Arif Fishing 2018) and in at least one lake in Bucharest (Ciobanu, Mircea, pers. comm.; Iftime and Iftime, pers. obs., 2020 - Fig. 6). There are no indications of reproduction so far. Also, it occurs in the Hungarian stretch of the Crișul Repede/Sebes Körös river (Telcean et al. 2005; Telcean and Cupșa, 2009). (The record of the similar American species Micropterus dolomieu Lacepède, 1802, from a backwater of the Râul Negru in Covasna County (Hegyeli 2007), needs to be confirmed by further research - Hegyeli, Zs., ap. Oțel, V., pers. comm.)

\section{Ord. Perciformes}

Fam. Moronidae

Morone saxatilis (Walbaum, 1792) X Morone chrysops (Rafinesque, 1820). Common name(s): English: Palmetto Bass (if the male in the cross was M. chrysops and the female M. saxatilis), Sunshine Bass (the reciprocal cross) (Hodson 1989). Both parental species are native to North American coastal (M. saxatilis) or inland (M. chrysops) waters (Froese and Pauly 2019). Such hybrids can occasionally reproduce, 
but with very low success (Kizak and Güner 2014). It was introduced near Bucharest, at Tâncăbești (Andy Arif Fishing 2018; Ciobanu, Mircea, pers. comm.), labelled as "striped bass" - however, the available video (Andy Arif Fishing 2018) shows the characteristic broken-line pattern of the hybrid, instead of the continuous-line pattern of the true striped bass, M. saxatilis (Hodson 1989; Bariche et al. 2020). This hybrid was also found in the Serbian Danube, close to the Romanian sector (Skorić et al. 2013).

Supraclass Tetrapoda

Class Amphibia

Ord. Anura

Fam. Ranidae

Pelophylax (ridibundus) kurtmuelleri (Gayda, 1940). Common name(s): English: Balkan Water Frog (e.g., Kolenda et al. 2017). This taxon is considered native to most of Greece, Albania, Northern Macedonia, Montenegro, southern Serbia, south-western Bulgaria (Lukanov et al. 2015; Kolenda et al. 2017; Vucić et al. 2018),

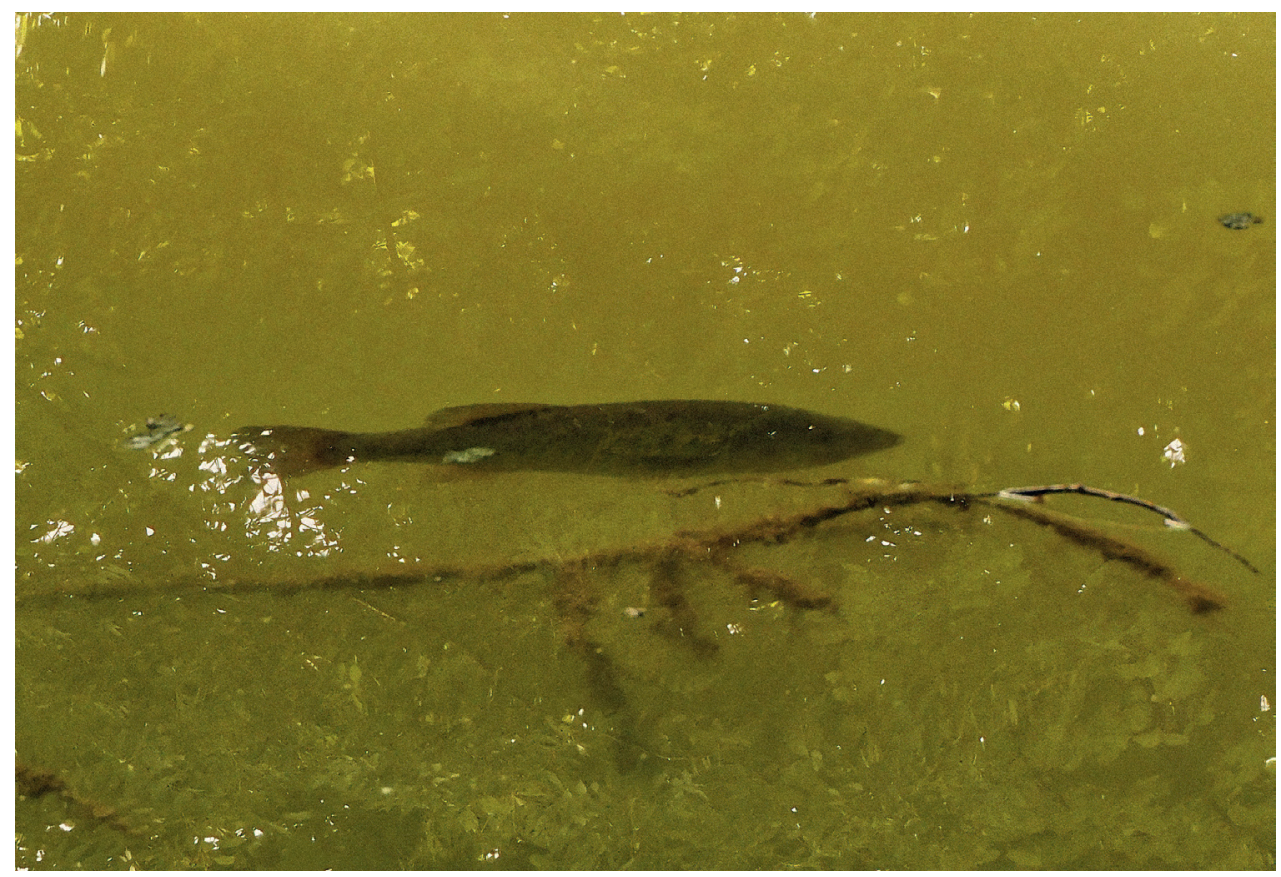

Figure 6. Micropterus salmoides, Bucharest, lake in National Stadium Park, 2020, photo A. Iftime. 
but widely introduced across Europe, probably mainly together with fish stocks (see, e.g., Kolenda et al. 2017; Bisconti et al. 2019). In Romania, a few specimens were determined through molecular protocols to pertain to Pelophylax kurtmuelleri (as opposed to the widespread Pelophylax ridibundus) (Marosi et al. 2014; Vucić et al. 2018). For some of these the collecting locality is not given (Marosi et al. 2014), and another was identified by Plötner et al. (2008) from the Sfântu Gheorghe arm of the Danube near Murighiol (Tulcea county), determined as P. ridibundus (see Plötner et al. 2008, Appendix S1) and later as P. kurtmuelleri (Vucić et al. 2018; see Litvinchuk et al. 2020 - and here it is worth mentioning that the results differ from Plötner et al. 2008 for one of the markers and in some of the specimens, which raises certain doubts with respect to the relevance of such analysis). Thus, $P$. kurtmuelleri (or its allelic markers, naturally encompassing at least part of the same polymorphism as $P$. ridibundus - i. e. not very specific - or derived from backcross hybridization with $P$. ridibundus) may be native, naturally spread in Eastern Europe, north of the "classic" areal (Herczeg et al. 2016; Kolenda et al. 2017; Litvinchuk et al. 2020). Moreover, $P$. kurtmuelleri and P. ridibundus (and European Pelophylax bedriagae) are sometimes seen as biologically conspecific, with no reproductive barrier (Hotz et al. 2013, on a molecular basis only) and sometimes as distinct, with P. kurtmuelleri - P. ridibundus F2 hybrids unviable and backcross individuals (F1 x parental species) sterile (Plötner et al. 2010). Clearly, hybridization is possible (Dufresnes et al. 2017) but this is most likely impaired by strong (but not total) hybrid dysfunction, as per Plötner et al. 2010, while the results of Hotz et al. 2013, may be explained by low specificity of the markers used, coupled with a limited amount of gene flow through the few fertile hybrids (see also the discussion by Papežík et al. 2021, including the gene flow hypothesis).P. kurtmuelleri and $P$. ridibundus widely overlap in morphological and morphometric characteristics (Papežík et al. 2021). The calls of $P$. kurtmuelleri are distinct, especially when in sympatry, from those of $P$. ridibundus - but whatever the song differences, even valid species do not segregate by song type and hybridize despite differences in calls (Lukanov et al. 2015). Therefore, P. kurtmuelleri, even if often treated as part of $P$. ridibundus (Speybroeck et al. 2016; Speybroeck et al. 2020) is most probably a valid species, but its Romanian records may represent either misidentified (due to low marker specificity) $P$. ridibundus, or naturally occurring recombinants. Hence the doubtful status of P. kurtmuelleri both as a Romanian record and as a non-native species in Romania.

Class Reptilia

Ord. Squamata

Fam. Gekkonidae

Mediodactylus danilewskii (Strauch, 1887). Common name(s): English: Bulgarian Bent-toed Gecko (Speybroeck et al. 2020), Romanian: "gecko cu degete subțiri" 
(Panaitescu 2019a). The species is native to the Eastern Balkans, Anatolia, Crimea and some Greek islands (Kostakiozi et al. 2018). It was introduced (possibly vehiculated with merchandise and/or transit minibuses) in Bucharest, on dilapidated buildings and adjacent trees; a single specimen was recorded in 2018, then a population was found in 2019 (Panaitescu 2019a5; Cioflec 2019a; see also discussion at Gherghel and Tedrow 2019, and Koynova et al. 2020) which survived the next winter, and predation by numerous free-ranging cats (Cioflec 2020); adults and subadults were observed by us (Iftime and Iftime pers. obs., 2019-2020 - Fig. 7). Morphological characteristics (Tzankov 2007; Ajtić 2014) are sufficient for the identification of M. danilewskii in the context of treating forms in the M. kotschyi complex as full species (Kostakiozi et al. 2018). Its introduction has no detrimental consequences, and it has not been observed to spread beyond urban settings after introductions (Urošević et al. 2016).

Hemidactylus turcicus (Linnaeus, 1758). Common name(s): English: Mediterranean House Gecko, Turkish Gecko (Uetz et al. 2020). The species is native to the

5 Many reptile species, including this, were discovered through reporting by nature-interested people without formal training in Biology (citizen science contributors) (Panaitescu, 2019a).

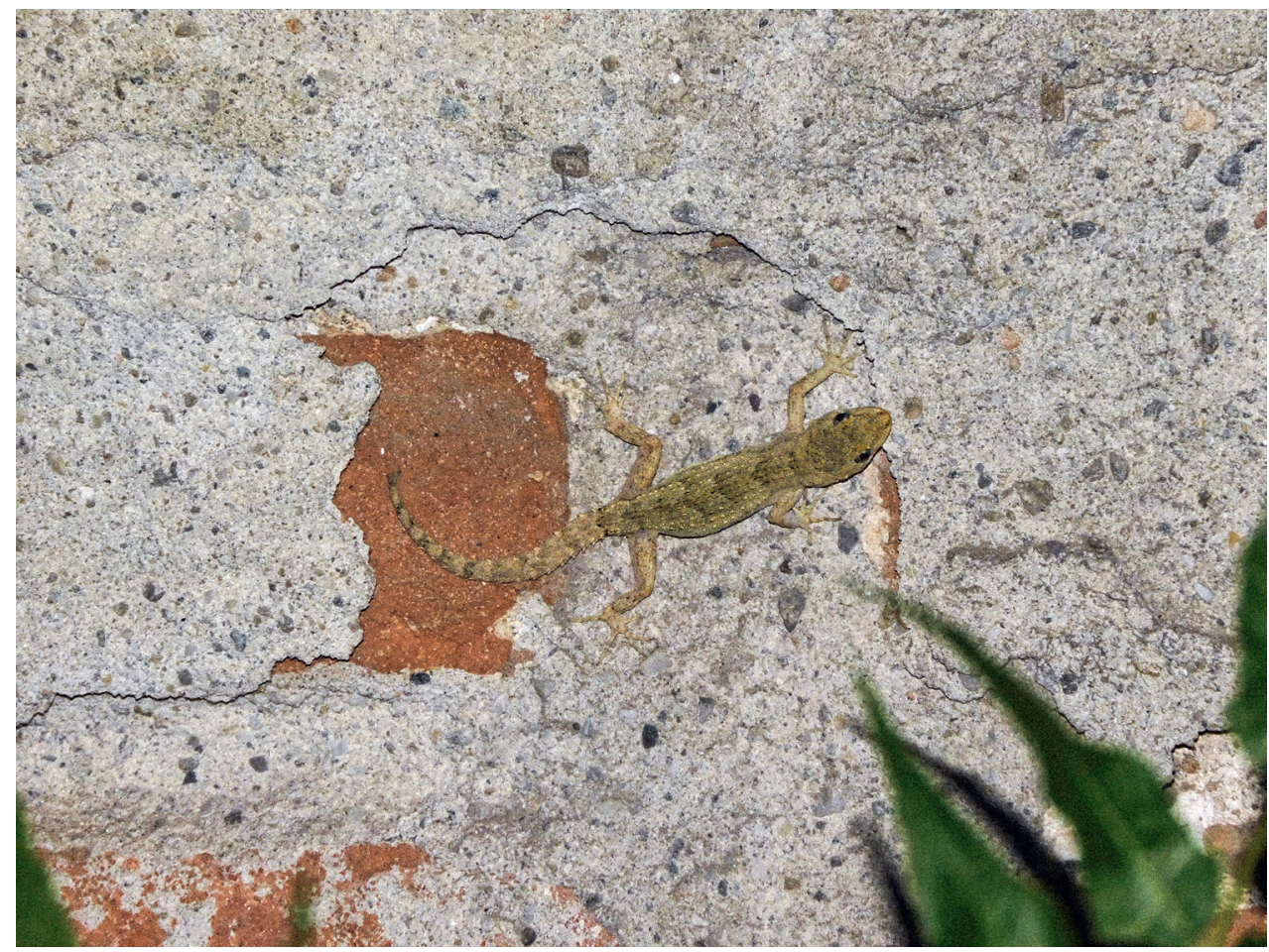

Figure 7. Mediodactylus danilewskii, adult, Bucharest, 2020, photo O. Iftime. 
Mediterranean basin (Uetz et al. 2020). One live specimen was found in 1998 on the Romanian seashore (Panaitescu, D., ap. Dragomir 2021).

Fam. Phyllodactylidae

Tarentola mauritanica (Linnaeus, 1758). Common name(s): English: Moorish Gecko (Speybroeck et al. 2020), Romanian: "gecko de perete maur" (Panaitescu 2021). The species is native to the Eastern Balkans, Anatolia, Crimea and some Greek islands (Kostakiozi et al. 2018). One live specimen was found in December 1995 as an adventive arrival upon merchandise from Spain, on the Otopeni airport (Crăciun, N., pers. comm.); it was finally fixed ("Grigore Antipa" National Museum of Natural History collection). A second specimen was found in 2019 in Oradea (Panaitescu, D., ap. Dragomir 2021) and a third (also in winter) in Sibiu, having been imported with building materials from Italy (Panaitescu 2021).

Fam. Lacertidae

Podarcis siculus (Rafinesque-Schmaltz, 1810). Common name(s): English: Italian Wall Lizard (Speybroeck et al. 2020), Romanian: "şopârlă italiană de ziduri" (Cioflec 2019-2020). The species is native to Italy and other more or less disjunct Mediterranean regions (Speybroeck et al. 2020). It was introduced (presumably vehiculated with garden plants) in Bucharest, in a park-like setting where numerous specimens were observed (2019); later (2020) it was found in Alba Iulia (Alba county) (Cioflec 2019-2020). The Bucharest population appears to be thriving, with numerous specimens across all age classes (Iftime and Iftime, pers. obs., 2019-2020 - Fig. 8). It is considered a potential threat for other lizards if introduced into their habitat, but examples of serious impact have so far been from Mediterranean islands with endemic native Podarcis species with close ecological niches to that of $P$. siculus (see Adamopoulou and Pafilis 2019, and literature quoted therein). In our opinion it should be further studied whether on Mediterranean islands poor habitat bioproductivity contributes to increased competition and therefore increased impact of $P$. siculus introduction. It is vulnerable to cat predation, an introduced population in Athens being depleted as much from stray cat predation as from a human eradication project (Adamopoulou and Pafilis 2019).

Fam. Agamidae

Subfam. Agaminae

Phrynocephalus mystaceus (Pallas, 1776). Common name(s): English: Bearded Toad Agama (Ananjeva et al. 2006). The species is native to Central Asia and the Northern Caucasus (Ananjeva et al. 2006). One live specimen was found in August 1986 in 


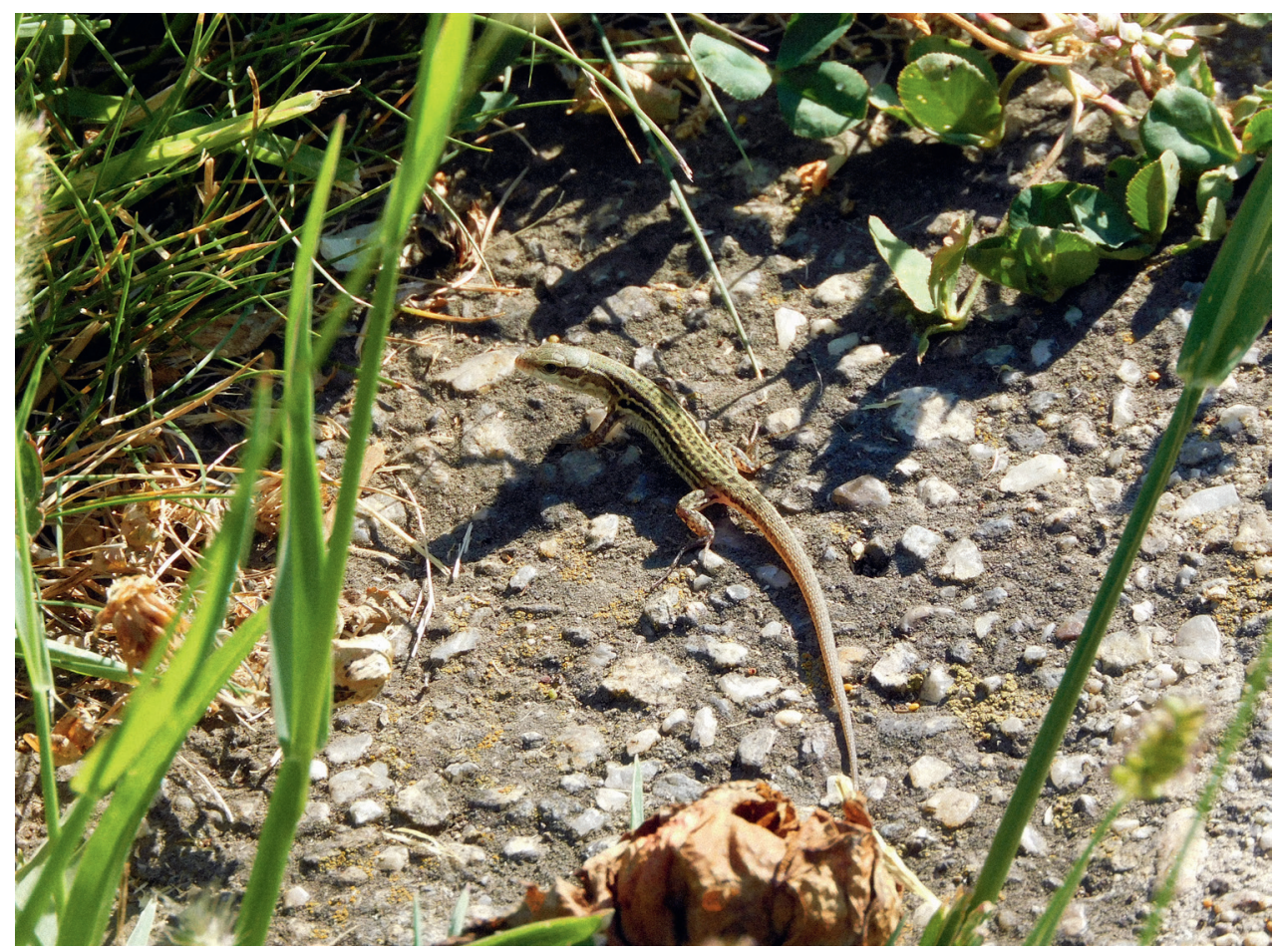

Figure 8. Podarcis siculus, juvenile, Bucharest, 2020, photo O. Iftime.

Bucharest, possibly vehiculated with merchandise or equipment; it subsequently died (Andrei 1987).

Fam. Varanidae

Varanus exanthematicus (Bosc, 1792). Common name(s): English: Savannah Monitor (Uetz et al. 2020). The species is native to Western and Central sub-Saharan Africa (Uetz et al. 2020). One specimen, most likely a terrarium escape/release, was found (ca. 2016), at Cristuru Secuiesc (Harghita county) killed by dogs, after having consumed a juvenile dog itself (T. Sos apud Testoase.com 2016).

Fam. Pythonidae

Python (molurus) bivittatus Kuhl, $1820^{6}$. Common name(s): English: Burmese Python (Uetz et al. 2020). The species is native to South-East Asia (Uetz et al. 2020). One adult

6 Despite widespread reception of P. bivittatus as distinct from P. molurus (Uetz et al. 2020, and literature quoted therein) it appears that hybrids between the two are fertile and most likely prolific (Barker and Barker 2008; Hunter et al. 2018 - the last paper speaking about "taxonomic uncertainty 
specimen, most likely a terrarium escape/release, was found and killed by villagers in November 1997, close to Lake Snagov (Ilfov county) (Andrei, M.-D., pers. comm.; "Grigore Antipa" National Museum of Natural History collection).

Fam. Colubridae

Elaphe (quatuorlineata) quatuorlineata (Lacépède, 1789) ${ }^{7}$. Common name(s): English: Four-lined Snake (Uetz et al. 2020). The species is native to Italy and the western Balkans (Uetz et al. 2020). One specimen, most likely a terrarium escape/release, was found in Bucharest (Panaitescu 2019b).

Ord. Testudines

Fam. Emydidae

Trachemys scripta (Thunberg in Schoepff, 1792). Common name(s): English: Pond Slider (general), Yellowbelly Slider - subspecies T. s. scripta, Red-eared Slider - subspecies T. s. elegans (Wied, 1838) (Uetz et al. 2020), Romanian: țestoasă de Florida, țestoasă cu tâmple galbene (T. s. scripta), țestoasă cu tâmple roșii (T. s. elegans) (Cioflec 2017-2021). The species is native to North America (Uetz et al. 2020). It was introduced by deliberate release of aqaterrarium specimens (especially as they grew up); import and release started soon after 1989 (Sos 2007). Specimens released pertain to two subspecies: T. s. scripta and T. s. elegans (Cioflec 2017-2021); the formerly recognized subspecies T. s. troosti (Holbrook, 1836), also found in Romania (Cioflec, 2017-2021) is most likely a natural intergrade between T. s. scripta and T. s. elegans (Parham et al. 2020). Besides those, we could observe specimens with traits suggesting anthropogenic hybridization (as opposed to natural, "troosti" intergrades) between T. s. scripta and T. s. elegans, as per images of "anthropogenic hybrids" in Parham et al. 2020 (Iftime and Iftime, pers. obs., 2021). It is found mainly in urban park lakes, in and/or around the cities of Bucharest (Sos 2007; Stănescu et al. 2017; Cioflec 2017-2021; Iftime and Iftime, pers. obs., 2020-2021), Craiova, Râmnicu-Vâlcea, Constanța (Sos 2007; Stănescu et al. 2017; Iftime and Iftime, pers.

regarding species boundaries" in this and other instances in the genus Python). It is therefore advisable to maintain P. bivittatus as a subspecies of P. molurus.

7 Elaphe (quatuorlineata) sauromates is native to Romania. The separate species status for $E$. quatuorlineata and E. sauromates, as opposed to both being subspecies of E. quatuorlineata, has been long argued (Helfenberger 2001; Lenk et al. 2001; Utiger et al. 2002) and widely accepted (e.g. Uetz et al. 2020, Speybroeck et al. 2020) but, as also discussed by Iftime, 2010, reproductive isolation/ incompatibility between the two forms has not been actually investigated, quoted authors advocating for the split on the grounds of genetic distance and parapatric distribution with limited contact. Therefore, our position is that, pending data that would demonstrate such isolation/incompatibility, the split should be taken under reserve. 
obs., 2020), Oradea, Cluj-Napoca, Timișoara, Galați, Piatra-Neamț, Sibiu, Brașov, Târgu-Mureș (Sos 2007; Dimancea 2013; Stănescu et al. 2017), Bacău (Rotaru 2017), Botoșani (Tele'M Botoșani 2017), Ploiești (Brezeanu 2018; Iftime and Iftime, pers. obs., 2020), Buzău (Știri de Buzău 2017; Iftime and Iftime, pers. obs., 2020-2021), Târgoviște (Iftime and Iftime, pers. obs., 2020), Pitești (Iftime and Iftime, pers. obs., 2020), in thermal waters near Oradea (Gavriloaie et al. 2010; Iftime and Iftime, pers. obs., 2014) and also sporadically in large rivers such as the Someș (Sos 2009; GherlaInfo 2019b), Târnava Mare, Mureș, Olt, Dâmbovița and around Tulcea in the Danube Delta (Sos 2009), Șieu (Petruț 2019). However, signs of reproduction are so far sporadic and only from urban parks, in Constanța (Matei and Tudor 2014), Bucharest (Cioflec 2019b; Iftime and Iftime, pers. obs., 2020), Ploiești (Iftime and Iftime, pers. obs., 2020 - Fig. 9) and Craiova (Iftime and Iftime, pers. obs., 2020). Romanian studies and observations show coexistence of Trachemys scripta and the native Emys orbicularis and reproduction of the two species in the same basin (Matei and Tudor 2014; Iftime and Iftime, pers. obs., 2020). The oft-repeated assertion that the two species compete to the detriment of E. orbicularis (e.g. Cadi and Joly 2003) has been again and again challenged, at least for some areas of Europe (see, e.g., Macchi et al. 2008; Kleewein 2015). In our opinion the ecological effect of marginal/ suboptimal habitats of E. orbicularis in southern Europe may increase the impact of T. scripta. In Romania, whatever competition there is does not prevent the healthy

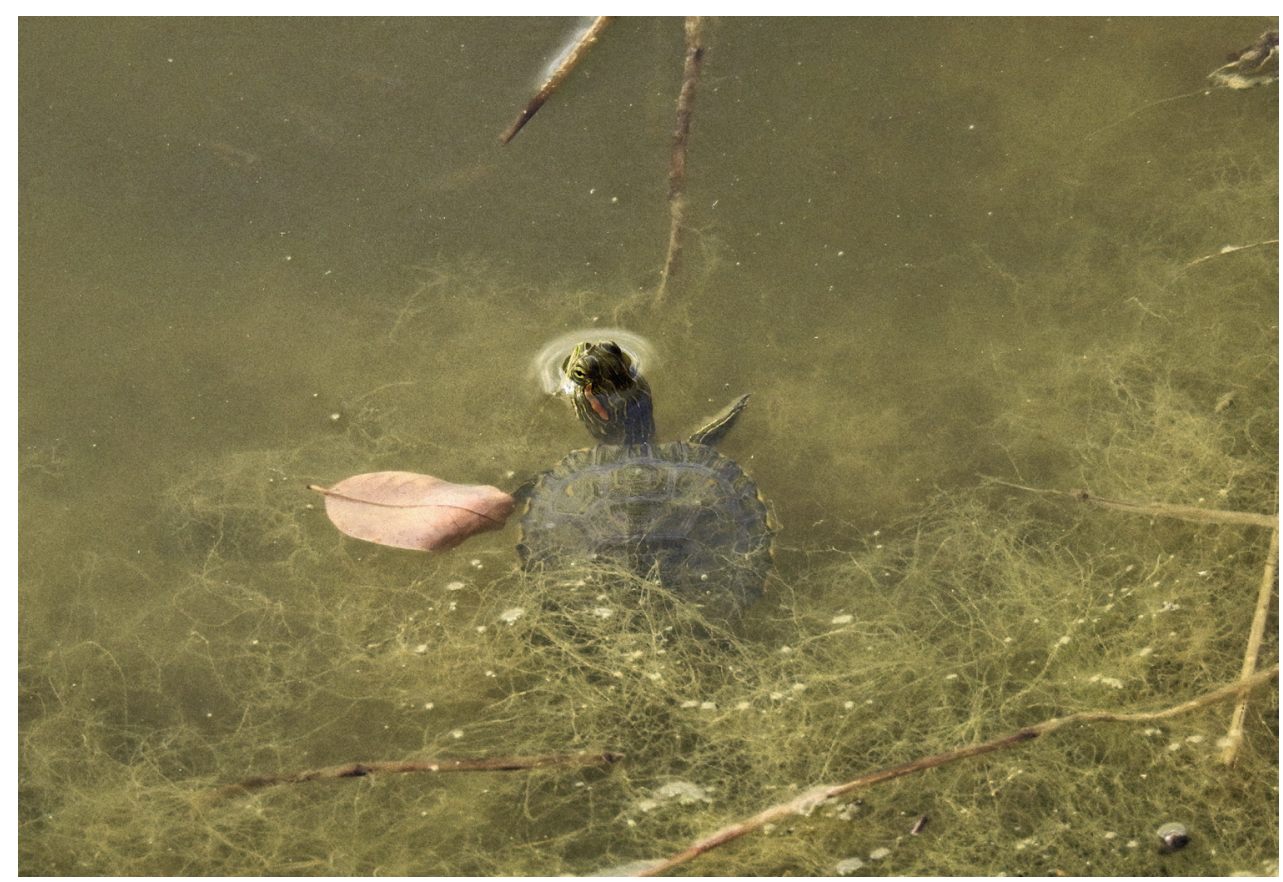

Figure 9. Trachemys scripta elegans, juvenile, lake in C. Stere Park, Ploieşti, 2020, photo A. Iftime. 
reproduction of both species in a syntopic setting (Matei and Tudor 2014). They overlap but partly in diet, as T. scripta is more phytophagous and opportunistic than the predominantly carnivorous E. orbicularis (Pérez-Santigosa et al. 2011) and seem to rather differ in their actual sunning preferences (Iftime and Iftime, pers. obs.).

Graptemys pseudogeographica (Gray, 1831). Common name(s): English: False Map Turtle - subspecies G. p. pseudogeographica, Mississippi Map Turtle - subspecies G. p. kohnii (Baur, 1890) (Uetz et al. 2020), Romanian: "țestoasă hartă falsă" (G. p. pseudogeographica), "țestoasă hartă de Mississippi" (G.p. kohnii) (Cioflec 2017-2021). The species is native to North America (Uetz et al. 2020). Both the nominate subspecies and G. p. kohnii are found in Romania (Cioflec 2017-2021; Iftime and Iftime, pers. obs., 2020-2021). It was introduced (ca. 2013) in the same way as Trachemys scripta, and is found in Bucharest (Cioflec 2017-2021; Iftime and Iftime, pers. obs., 2020-2021) but also in Buzău (Iftime and Iftime, pers. obs., 2020-2021), Pitești and Ploieşti (Iftime and Iftime, pers. obs., 2020 - Fig. 10). There is no evidence of reproduction so far (though, quite small specimens were observed in Bucharest in 2021 - Iftime and Iftime, pers. obs., 2021, but the release of commercially acquired juveniles cannot as yet be excluded).

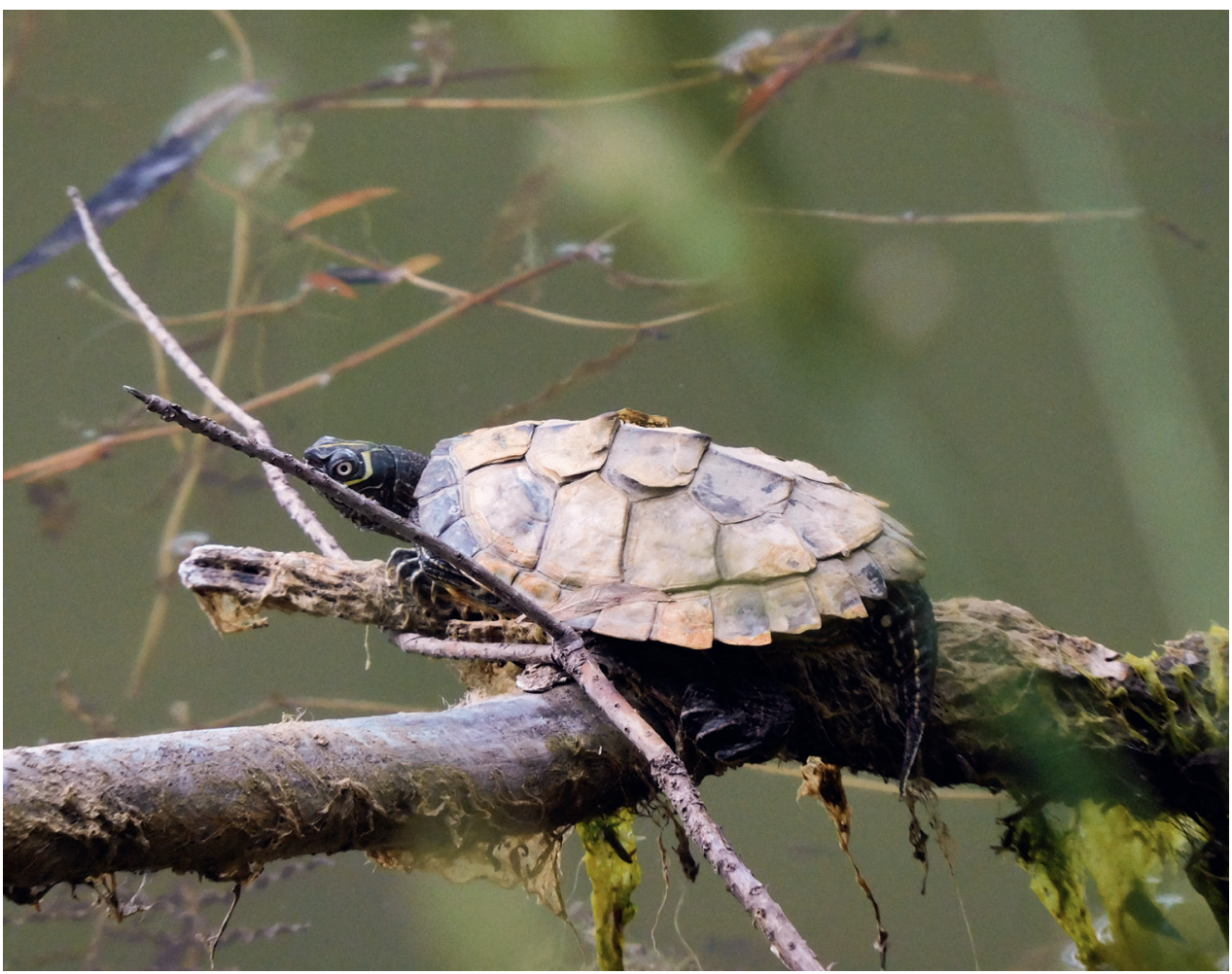

Figure 10. Graptemys pseudogeographica kohnii, Ploiești, lake in C. Stere Park, 2020, photo O. Iftime. 
Graptemys (pseudogeographica) ouachitensis (Cagle, 1953) ${ }^{8}$. Common name(s): English: Ouachita Map Turtle (Uetz et al. 2020), Romanian: "țestoasă hartă de Ouachita" (Cioflec 2017-2021). The species is native to North America (Uetz et al. 2020). It was introduced (ca. 2013) in the same way as Trachemys scripta, and is found in Bucharest (Cioflec 2017-2021; Iftime and Iftime, pers. obs., 2020-2021),

8 Graptemys turtles are in a complicated taxonomic situation, with some taxons fluctuating between the species and subspecies status. G. kohnii was reclassified as a subspecies of G. pseudogeographica, while G. ouachitensis was split from G. pseudogeographica; later G. sabinensis was split from $G$. ouachitensis (see Vogt 1993, Vogt 2018 and Uetz et al. 2020 for the taxonomic history of this group; Vogt 2018 argues for retaining G. sabinensis as a subspecies of G. ouachitensis). However, often the autors advocating for splits (e.g. Vog, 1993 for G. ouachitensis from G. pseudogeographica [see also discussion by Freedberg and Myer, 2012]; Lindeman 2013, for G. sabinensis from G. ouachitensis; Ennen et al. 2010 for another split in other Graptemys turtles) do not use the biological species concept. Reproductive incompatibility studies are few and do not cover the full spectrum of described forms. In the G. pseudogeographica species complex, of interest for us, a G. geographica X G. ouachitensis F1 hybrid female was apparently sterile (Vogt 2018) and there appears to be a decrease in fitness in G. geographica X G. pseudogeographica hybrid females (Freedberg and Myers 2012; Mitchell et al. 2016), but there is no indication (so far) for any incompatibility between G. pseudogeographica and G. ouachitensis (Freedberg and Myers 2012; Vogt 2018). An author observed numerous intermediatelooking specimens in the pet trade and assumed massive F1 and F2 hybridization between $G$. $p$. pseudogeographica, G. p. kohnii and G. ouachitensis (Lee 2012). Similarly, Sos 2008 (on Testoase. com) mentioned what he called G. p. ouachitensis X C. p. sabinensis hybrids being sold in Romanian pet shops. We would therefore consider G. ouachitensis (including G. sabinensis) to be better described as a subspecies of G. pseudogeographica, as G. (p.) ouachitensis.

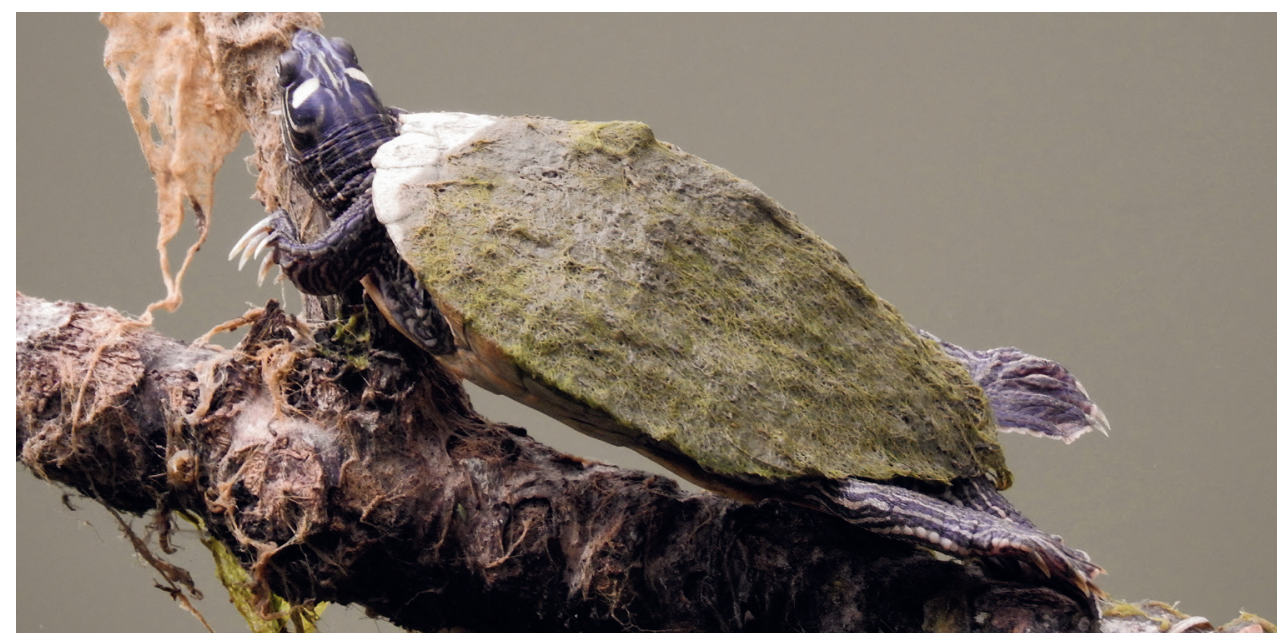

Figure 11. Graptemys (pseudogeographica) ouachitensis, Ploieşti, lake in C. Stere Park, 2020, photo A. Iftime. 
but also in Ploiești and Piteşti (Iftime and Iftime, pers. obs., 2020 - Fig. 11). There is no evidence of reproduction so far.

Pseudemys concinna (Le Conte, 1830). Common name(s): English: Eastern River Cooter (Uetz et al. 2020), Romanian: "țestoasă de râu" (Cioflec 2017-2021). The species is native to North America (Uetz et al. 2020). It was introduced (ca. 2016) in the same way as Trachemys scripta, and is found in Bucharest (Cioflec 2017-2021, Iftime and Iftime, pers. obs., 2020-2021), but also in Cluj (Ueda 2021, with data from 2019), and Râmnicu Vâlcea (Iftime and Iftime, pers. obs., 2020 - Fig. 12). There is no evidence of reproduction so far.

Pseudemys floridana (Le Conte, 1830) ${ }^{9}$. Common name(s): English: Florida Cooter (Uetz et al. 2020). The species is native to North America (Uetz et al. 2020). It was

9 Another difficult taxonomic situation. See Rhodin et al. 2017 presenting as potentially valid two alternative taxonomic options: a) P. peninsularis as a different species from the conspecific $P$. c. concinna and $P$. c. floridana and b) P. concinna as a different species from the conspecific $P$. f. floridana and $P$. $f$. peninsularis. See also Spinks et al. 2013, presenting a molecular phylogeny failing to produce well-defined Pseudemys species clusters (which, however, may reflect either hybridization or poor marker resolution). Following the biological species concept might, in the light of the few data on this subject, favour the b) option, as some degree of reproductive incompatibility was inferred between $P$. concinna and P. floridana (Crenshaw 1965) and there appears to be extensive intergradation between

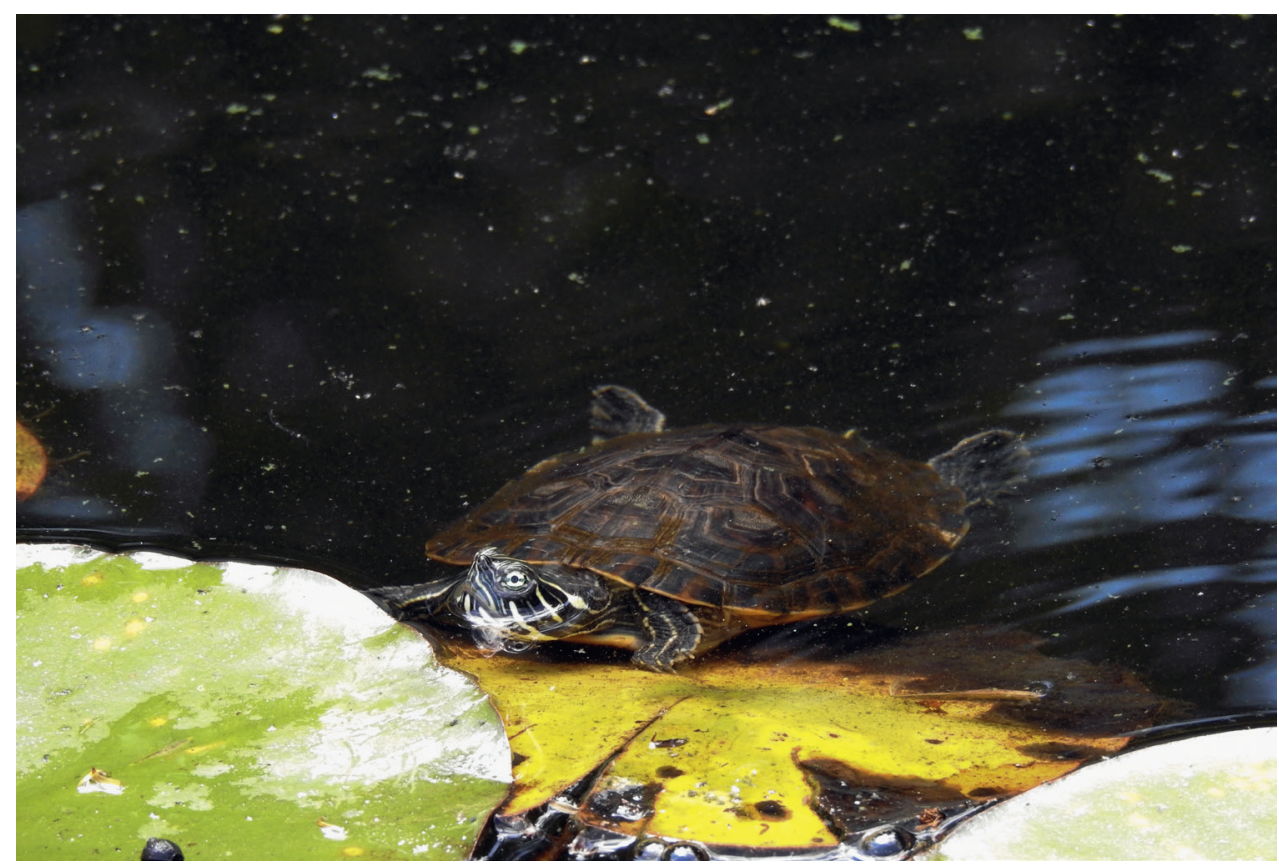

Figure 12. Pseudemys concinna, Râmnicu Vâlcea, pond in Zăvoi Park, 2020, photo O. Iftime. 
introduced (possibly ca. 2016) in the same way as Trachemys scripta, and is found in Bucharest (Iftime and Iftime, pers. obs., 2021 - Fig. 13). There is no evidence of reproduction so far.

Pseudemys (floridana) peninsularis Carr, $1930^{10}$. Common name(s): English: Peninsula Cooter (Uetz et al. 2020), Romanian: "țestoasă de peninsulă" (Cioflec 2017-2021). The species is native to North America (Uetz et al. 2020). It was introduced (ca. 2016) in the same way as Trachemys scripta, and is found in Bucharest (Cioflec 2017-2021; Iftime and Iftime, pers. obs., 2020-2021 - Fig. 14). There is no evidence of reproduction so far.

P. floridana and P. peninsularis (Aresco 2004) - see also Thomas and Jansen 2006, who follow variant b), but also conclude that more data are needed for a definite resolution of this problem.

10 See note above.

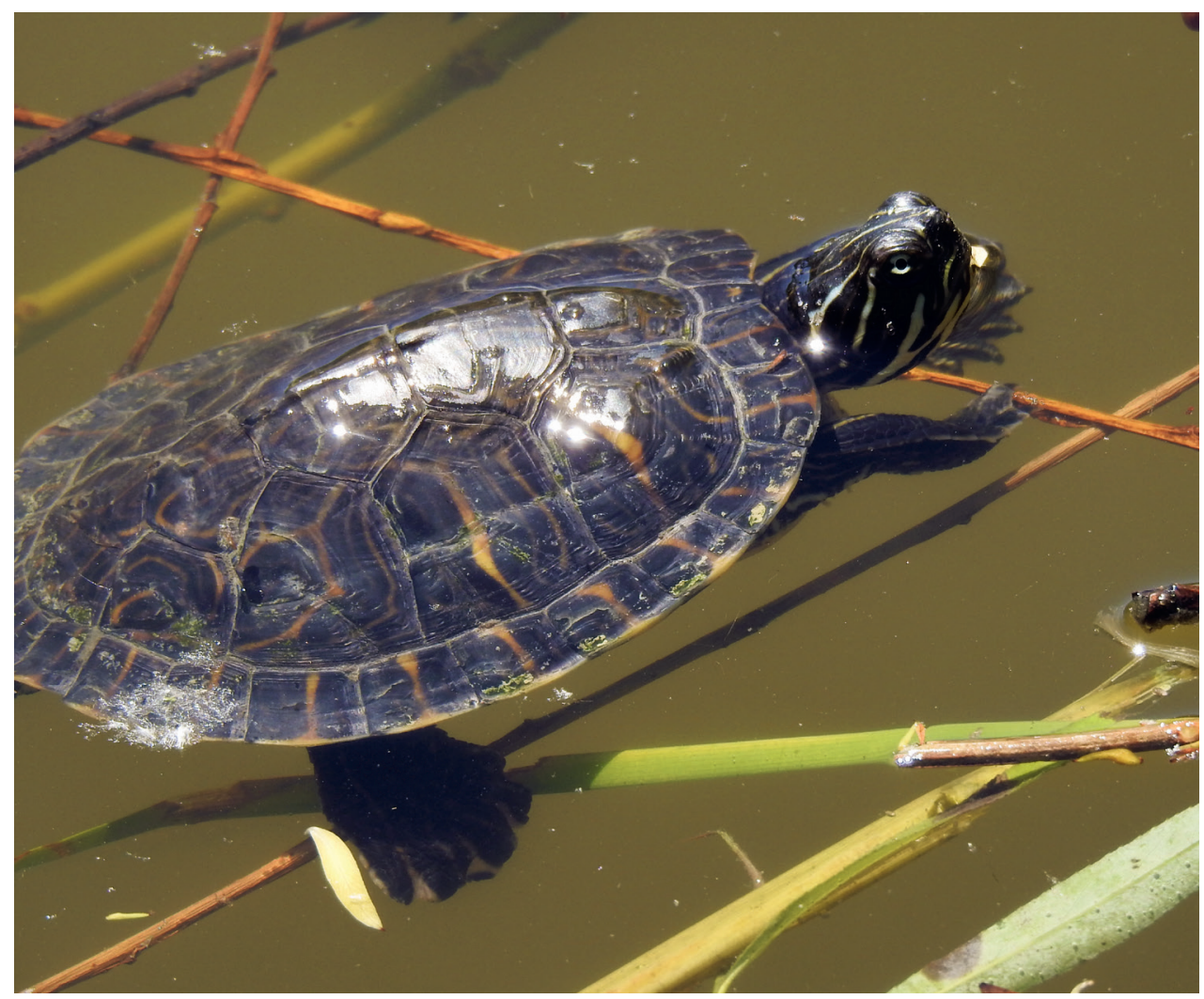

Figure 13. Pseudemys floridana, Bucharest, lake in Titan Park, 2021, photo A. Iftime. 


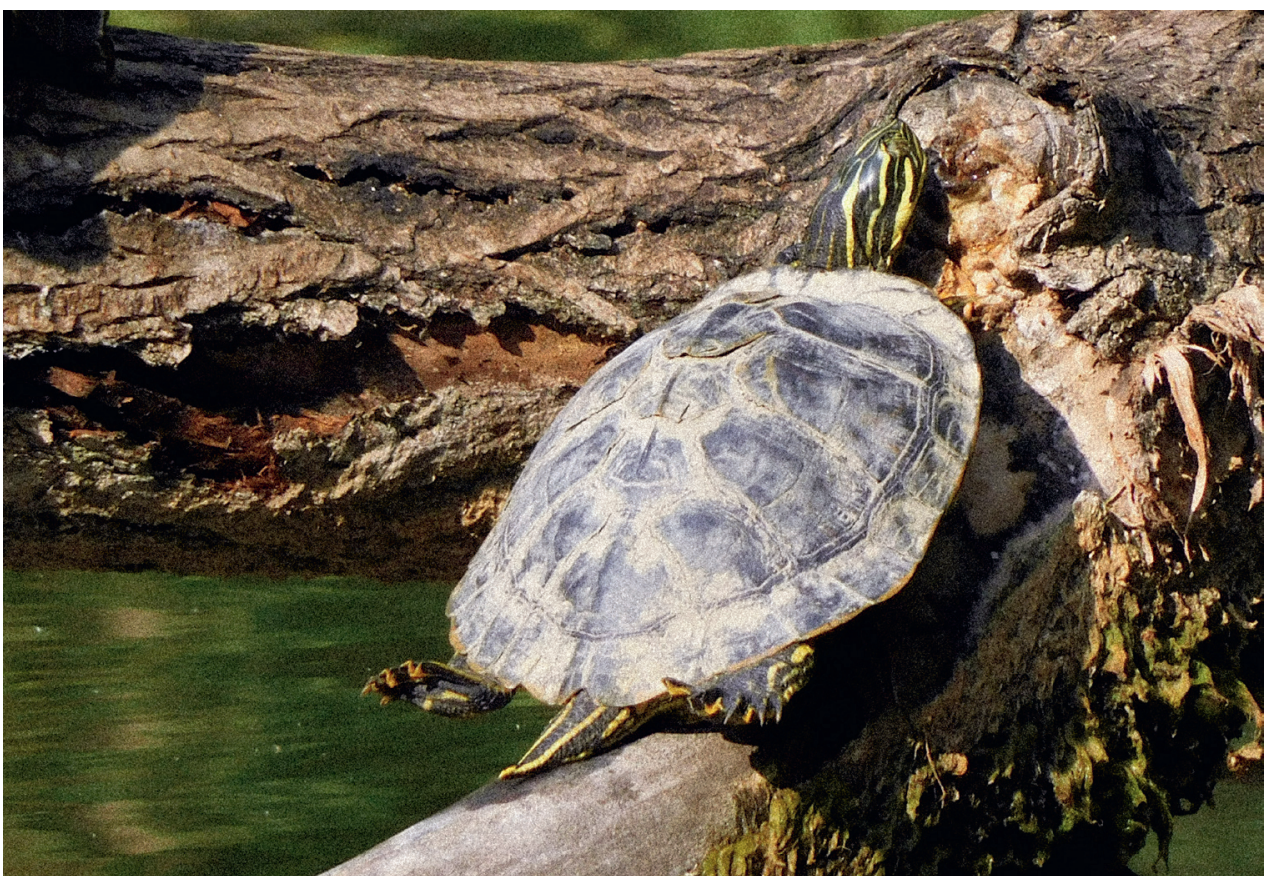

Figure 14. Pseudemys (floridana) peninsularis, lake in National Stadium Park, 2020, photo A. Iftime.

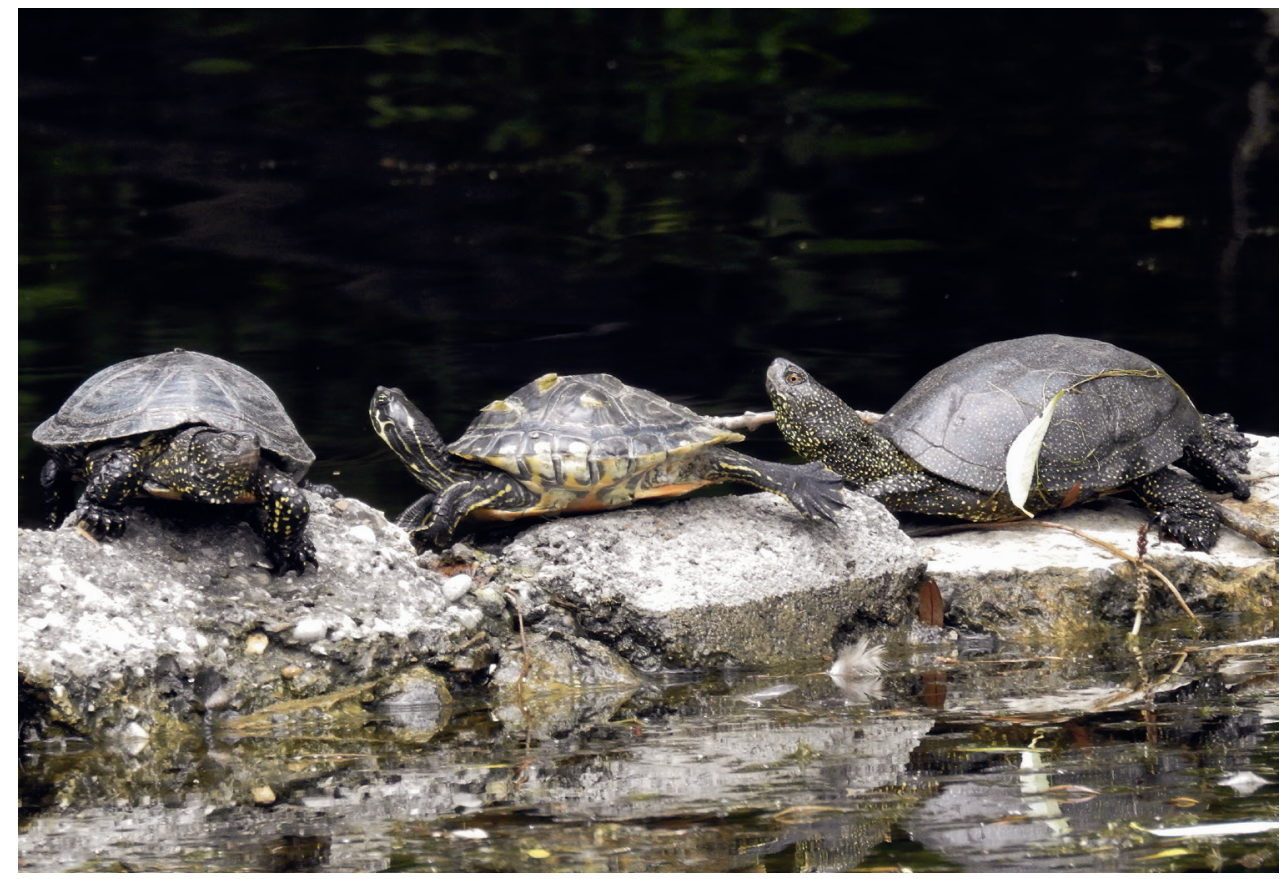

Figure 15. Pseudemys nelsoni, with Emys orbicularis, Buzău, lake in Crâng Park, 2020, photo A. Iftime. 
Pseudemys nelsoni Carr, 1938. Common name(s): English: Florida Redbelly Turtle (Uetz et al. 2020). The species is native to North America (Uetz et al. 2020). It was introduced in the same way as Trachemys scripta, and is found in Buzău (Iftime and Iftime, pers. obs., 2020 - Fig. 15) and Bucharest (Iftime and Iftime, pers. obs., 2021). There is no evidence of reproduction so far.

Fam. Geoemydidae

Mauremys sinensis (Gray, 1834). Common name(s): English: Chinese Striped-necked Turtle, Common Thread Turtle (Uetz et al. 2020), Romanian: "țestoasă chinezească cu gât dungat" (Cioflec 2017-2021). The species is native to East Asia (Uetz et al. 2020). It was introduced in the same way as Trachemys scripta, and is found in Bucharest (Panaitescu 2020; Cioflec 2017-2021; Iftime and Iftime, pers. obs., 2021 - Fig. 16). There is no evidence of reproduction so far.

Mauremys reevesii (Gray, 1831). Common name(s): English: Reeves' Turtle (Uetz et al. 2020), Romanian: "țestoasă chinezească de iaz" (Cioflec 2017-2021). The species is native to East Asia (Uetz et al. 2020). It was introduced in the same way as Trachemys

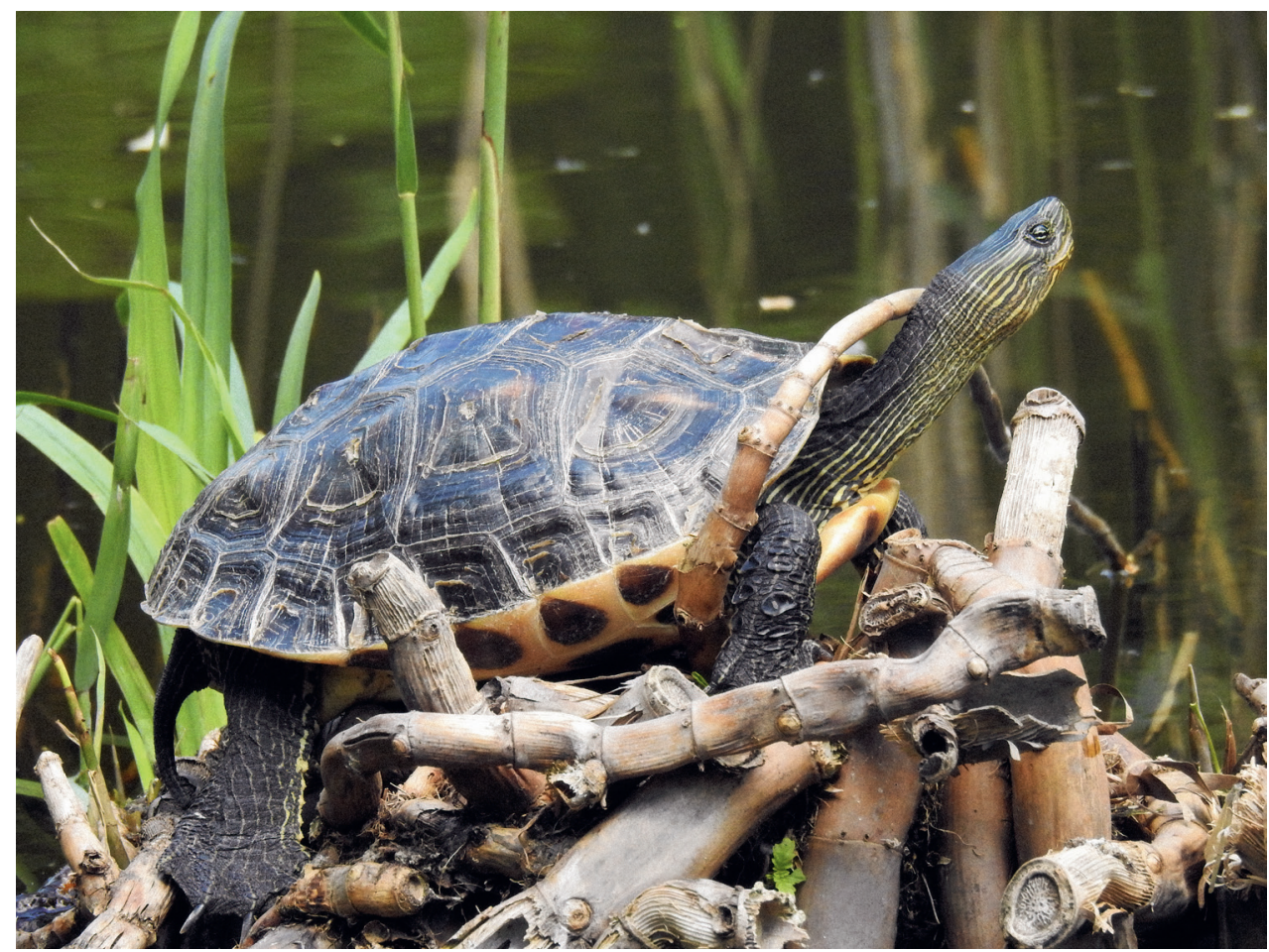

Figure 16. Mauremys sinensis, Bucharest, lake in Botanical Garden, 2021, photo A. Iftime. 
scripta, and is found in the Bucharest area (Cioflec 2017-2021). There is no evidence of reproduction so far.

Fam. Trionychidae

Pelodiscus sinensis (Wiegmann, 1835). Common name(s): English: Chinese Softshelled Turtle, Common Thread Turtle (Uetz et al. 2020), Romanian: "țestoasă chinezească cu carapace moale" (Cioflec 2017-2021). The species is native to East Asia (Uetz et al. 2020). It is found in Bucharest (Cioflec 2017-2021; Iftime and Iftime, pers. obs., 2021) - Fig. 17. Morphological characteristics are sufficient for the identification of $P$. sinensis (Farkas et al. 2019) in the context of treating forms in the P. sinensis complex as full species (Fritz et al. 2010). There is no evidence of reproduction so far.

\section{Discussion}

Our tally differs from that of Stănescu et al. 2020, which use two cathegories of alien species: "casual", i.e. those "that are surviving in the new habitat but are not spreading", and "established", i. e. "reproducing and spreading, with some becoming

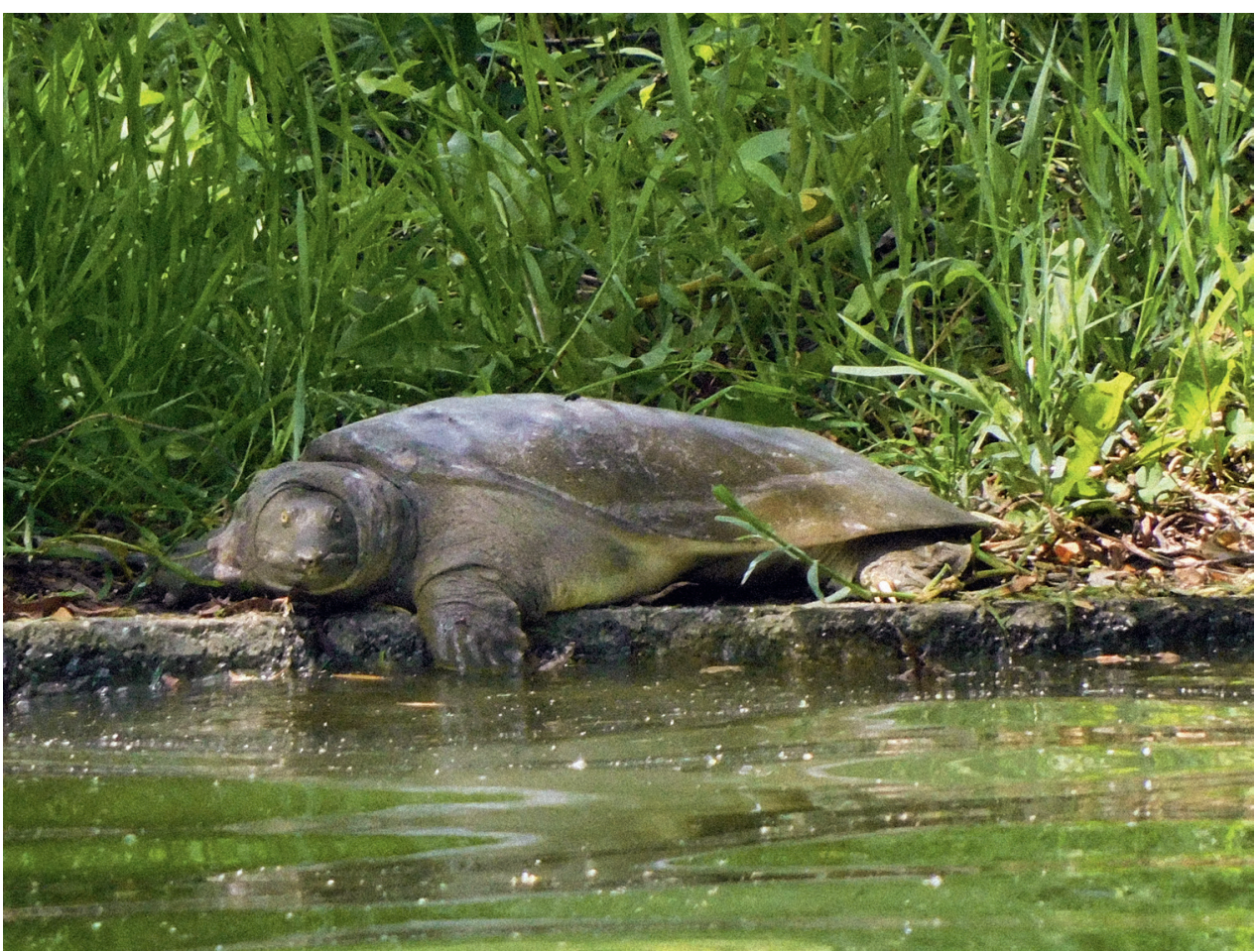

Figure 17. Pelodiscus sinensis, Bucharest, lake in Titan Park, 2021, photo O. Iftime. 
invasive" (Stănescu et al. 2020), and list 29 fish species, 18 of them "casual" and 11 "established", and two reptiles, both "casual". However, they include as "casual" species no longer present in Romania (Parabramis pekinensis, Megalobrama terminalis) or for which there is no indication of even transient survival in free-ranging condition (Clarias ngamensis) while neglecting species which were at least found alive together with Parabramis and Megalobrama (Ochetobius elongatus, Xenocypris macrolepis and other Asiatic species with the same introduction history, see above), had/still have self-sustaining populations for some time (Mediodactylus danilewskii) or which did survive for some time (and may still be found) free-ranging in Romanian waters (Acipenser baerii), and rejecting those definitely established and reproducing, but only in a thermal environment (e.g. Macropodus opercularis and other aquarium fishes, see above). Also, they overlook significant evidence towards the native status of Carassius (auratus) gibelio (see, e.g., Oțel 2019) and treat it as alien without even mentioning the alternative perspective, which we consider to be better argued. Clearly, there is need of more detailed discussion and at the same time more consistent criteria ${ }^{11}$. By

11 Defining/ascertaining native versus non-native status is generally problematic, not only in fish species, in Stănescu et al. 2020. Thus, Capra ibex "cannot be considered alien since fossil remains were found in Peştera cu Oase (cave), Romania” (Stănescu et al. 2020, p. 595) but Cervus (Dama) dama is listed as non-native (Stănescu et al. 2020, p. 585) despite being known from Romanian (sub) fossil remains (see, e.g. Bindea 2006, and literature quoted therein).

Table 1. Alien species (fishes, amphibians, reptiles) found in Romania, with discussion of established and invasive status.

\begin{tabular}{lll}
\hline Species & $\begin{array}{l}\text { Established (self-reproducing } \\
\text { populations) }\end{array}$ & $\begin{array}{l}\text { Invasive in Romania (criteria after } \\
\text { IUCN, 2017; Romanian law) }\end{array}$ \\
\hline Fishes & No & No \\
\hline Polyodon spathula & No & No \\
Acipenser baerii & No & No \\
Carassius (auratus) auratus & No & No \\
Pethia conchonius & No & No \\
Pethia ticto & Yes & Unclear, likelier no or limited \\
Hypophthalmichthys molitrix & Probably & Probably not \\
Hypophthalmichthys nobilis & No & No \\
Ochetobius elongatus & No & No \\
Xenocypris macrolepis & No & No \\
Pseudobrama simoni & Yes & Probably not \\
Ctenopharyngodon idella & No & No \\
Mylopharyngodon piceus & No & No \\
Squaliobarbus curriculus & No & No \\
Parabramis pekinensis & No & No \\
Megalobrama terminalis & No & No \\
Hemiculter leucisculus & No & No \\
Toxabramis argentifer & No & No \\
Pseudolaubuca engraulis & Yes & Unclear \\
Pseudorasbora parva & No & No \\
Ictiobus niger & &
\end{tabular}


Table 1. (continued)

\begin{tabular}{|c|c|c|}
\hline Species & $\begin{array}{l}\text { Established (self-reproducing } \\
\text { populations) }\end{array}$ & $\begin{array}{l}\text { Invasive in Romania (criteria after } \\
\text { IUCN, 2017; Romanian law) }\end{array}$ \\
\hline Ictiobus bubalus & No & Not \\
\hline Ictiobus cyprinellus & No & No \\
\hline Piaractus brachypomus & No & No \\
\hline Ameiurus nebulosus & Yes & Unclear \\
\hline Ameiurus melas & Yes & Unclear \\
\hline Ictalurus punctatus & Possibly & No \\
\hline Clarias gariepinus & No & No \\
\hline Coregonus albula & Unclear, unlikely & No \\
\hline Coregonus maraenoides & Probably & No \\
\hline Coregonus peled & Unclear, unlikely & No \\
\hline Oncorhynchus mykiss & Yes & No \\
\hline Salvelinus fontinalis & Yes & No \\
\hline Salvelinus alpinus & No & No \\
\hline Perccottus glenii & Yes & Probably yes \\
\hline Macropodus opercularis & Yes (thermal waters) & No \\
\hline Trichopodus trichopterus & Yes (thermal waters) & No \\
\hline Betta splendens & No (doubtful even as introduction) & No \\
\hline Oreochromis niloticus & No & No \\
\hline Chindongo demasoni & No & No \\
\hline Lithochromis rufus & No & No \\
\hline Gambusia holbrooki & Yes (temperature-constrained) & Unclear, potential \\
\hline Poecilia reticulata & No & No \\
\hline Poecilia sphenops & Unclear (thermal waters) & No \\
\hline Xiphophorus helleri & No & No \\
\hline Xiphophorus maculatus & No & No \\
\hline Planiliza haematocheila & Yes & Unclear \\
\hline Lepomis gibbosus & Yes & Unclear \\
\hline Micropterus salmoides & No & No \\
\hline Morone saxatilis X Morone chrysops & No & No \\
\hline \multicolumn{3}{|l|}{ Amphibians } \\
\hline Pelophylax kurtmuelleri & Unclear & Unclear \\
\hline \multicolumn{3}{|l|}{ Reptiles } \\
\hline Mediodactylus danilewskii & Yes & No \\
\hline Hemidactylus turcicus & No & No \\
\hline Tarentola mauritanica & No & No \\
\hline Podarcis siculus & Yes & No \\
\hline Phrynocephalus mystaceus & No & No \\
\hline Varanus exanthematicus & No & No \\
\hline Python (molurus) bivittatus & No & No \\
\hline Elaphe (quatuorlineata) quatuorlineata & No & No \\
\hline Trachemys scripta & Yes & Likelier not \\
\hline Graptemys pseudogeographica & No & No \\
\hline Graptemys (pseudogeographica) ouachitensis & No & No \\
\hline Pseudemys concinna & No & No \\
\hline Pseudemys floridana & No & No \\
\hline Pseudemys peninsularis & No & No \\
\hline Pseudemys nelsoni & No & No \\
\hline Mauremys sinensis & No & No \\
\hline Mauremys reevesii & No & No \\
\hline Pelodiscus sinensis & No & No \\
\hline
\end{tabular}


our definitions ("introduced", even if known by only one record, and "established/ acclimatized", i.e. showing free-range reproduction) the list of non-native species is much more comprehensive (49 fishes, including one hybrid, 18 reptiles and one amphibian [Table 1], Pelophylax (ridibundus) kurtmuelleri, the presence and status of which are, however, doubtful, for the reasons discussed above and was therefore excluded from statistics) but only a limited number can be consider acclimatized, i.e. as reproducing unassisted in free ecosystems and persisting over the whole seasonal climatic spectrum (16 fishes and 3 reptiles - including cases of probable reproduction and species limited to thermal waters). Clear-cut empirical evidence for detrimental impacts upon native species, as required for the scientific (e.g., IUCN 2017) or legal (see OUG 57/2007, L49/2011 for Romanian law on the subject) definition of invasive species, exists only for one species (Perccottus glenii) and that is (for now) from outside Romania. Gambusia holbrooki is clearly detrimental for native species in other settings but is probably thermally constrained in Romania, for now at least, while a few other species (Pseudorasbora parva, Ameiurus nebulosus, A. melas, Planiliza haematocheila, Lepomis gibbosus) may have a detrimental impact upon some native species but this is debated or as yet unclear (see Fig. 18); moreover, fish impact upon amphibians is not limited to non-native fishes and is a recurrent factor in amphibian ecology (see, e.g., Hartel et al. 2007; Semlitsch et al. 2015). Other species are widely suspected of a detrimental impact, probably because of their "alien" status (Hypophthalmichthys molitrix, Trachemys scripta) but so far this has not been substantiated by a clearly associated decline of any native species. As for species known to have a detrimental impact in other areas, the uniqueness of local ecological conditions in Romania may have its consequences and has to be taken into account. Thorough ecological studies of the impact of non-native species should therefore be performed before any non-native species be considered "invasive" or "a

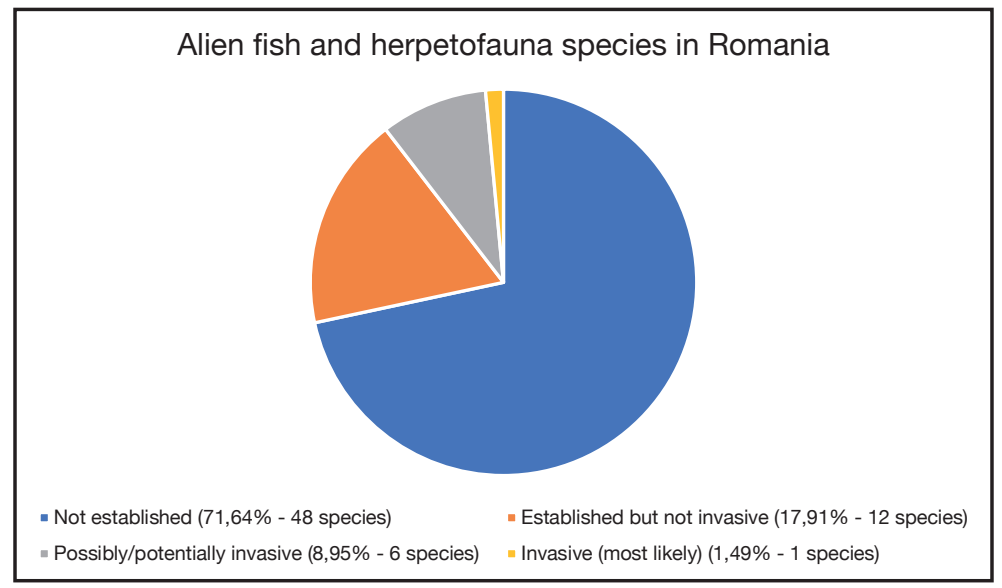

Figure 18. Established and invasive status of alien fish and herpetofauna species in Romania (invasivity criteria after IUCN and Romanian law). 
pest", and therefore a target of active management measures. However, even before such studies, maximal caution would suggest a "defensive" management that would ensure keeping local "insurance" populations of endangered species outside of the potential invasion range of non-native species potentially detrimental to them - and of course when such detrimental effects can be suspected by reasonable scientific presumtions correlating with data obtained in comparable ecological conditions (e.g. for Triturus dobrogicus as highly vulnerable to Perccottus glenii).

\section{Acknowledgements}

To Dr. Dale R. Jackson, Florida State University, and to Dr. Peter Lindeman, Edinboro University of Penssylvania, for their kind assistance by confirming our identifications of North American turtles; to Mr. Mircea-Dragomir Andrei, formerly curator of herpetology, "Grigore Antipa" National Museum of Natural History, and to Dr. Nicolae Crăciun, for sharing, at that time, information on the provenience of some specimens in the Museum herpetology collection; to the reviewers who improved the paper with comments and suggestions, and to Mr. Mircea Ciobanu, for sharing some information regarding fish introductions.

\section{References}

Adamopoulou CH, Pafilis P (2019) Eaten or beaten? Severe population decline of the invasive lizard Podarcis siculus (Rafinesque-Schmaltz, 1810) after an eradication project in Athens, Greece. Herpetozoa 32: 165-169.

Ajtić R (2014) Morphological, biogeographical and ecological characteristics of Kotschy's gecko (Cyrtodactylus kotschyi Steindachner, 1870 Gekkonidae) from the mainland portion of its distribution range. Fauna Balkana 3: 1-70.

Ananjeva NB, Orlov NL, Khalikov RG, Darevsky IS, Ryabov SA, Barabanov AV (2006) The reptiles of northern Eurasia. Taxonomic diversity, distribution, conservation status. Pensoft, $245 \mathrm{pp}$.

Anastasiu P, Rozylowicz L, Skolka M, Preda C, Memedemin D, Cogălniceanu D (2016) Alien species in Romania. In: Rat M, Trichkova T, Scalera R, Tomov R, Uludağ A (Eds) ESENIAS Reports 1. State of the art of alien species in South-Eastern Europe. Univ. of Novi Sad, Novo Sad, Serbia/IBER-BAS, Bulgaria, pp. 76-89.

Anastasiu P, Preda C, Bănăduc D, Cogălniceanu D (2017) Alien species of EU concern in Romania. Transylvanian Review of Systematical and Ecoogical Research 19(3) "The Wetlands Diversity": 93-106.

Andrei M (1987) Note on the occurrence of Phrynocephalus mystaceus Pall. 1776 (Reptilia, Agamidae) in Romania. Travaux du Museum National d'Histoire Naturelle "Grigore Antipa" 29: 209-211. 
Ardelean G, Beres I (2000) Fauna de vertebrate a Maramureşului. Ed. Dacia, Cluj-Napoca, 378 pp. [in Romanian]

Aresco MJ (2004) Reproductive ecology of Pseudemys floridana and Trachemys scripta (Testudines: Emydidae) in Northwestern Florida. Journal of Herpetology 38(2): 249-256. Arntzen JW, Wallis GP (1999) Geographic variation and taxonomy of crested newts (Triturus cristatus superspecies): morphological and mitochondrial DNA data. Bijdragen tot de Dierkunde 68(3): 181-203.

Bariche M, Al-Mabruk S, Ateș M, Büyük A, Crocetta F, Dristas M, Edde D, Fortič A, Gavriil E, Gerovasileiou V, Gökoğlu M, Huseyinoglu F, Karachle P, Kleitou P, Terbiyikkurt T, Langeneck J, Lardicci C, Lipej L, Pavloudi C, Pinna M, Rizgalla J, Rüștü Özen M, Sedano F, Tașkin E, Yildiz G, Zangaro F (2020) New alien Mediterranean biodiversity records 2020. Mediterranean Marine Science 21(1): 129-145.

Barker DG, Bakker TM (2008) The distribution of the Burmese Python, Python molurus bivittatus. Bulletin of the Chicago Herpetological Society 43(3): 33-38.

Bănăduc D, Stroillă V, Curtean-Bănăduc A (2013) The fish fauna of the Timiș river (Banat, Romania). Transylvanian Review of Systematical and Ecological Research 15 - special issue (2013), “The Timiş River Basin”: 145-172.

Bănăduc D, Bănăduc A, Lenhardt M, Guti G (2014) “Porțile de Fier/Iron Gates” gorges area (Danube) fish fauna. Transylvanian Review of Systematical and Ecological Research 16 - special issue (2014), The "Iron Gates" Natural Park: 171-196.

Bănărescu P (1963) Révision du genre Toxabramis Günther (Pisces, Cyprinidae). Bulletin du Muséum National d'Histoire Naturelle, Paris 35(5): 457-463. [in French]

Bănărescu P (1964) Fauna RPR, 13 (Pisces-Osteichthyes). Ed. Acad. R.P.R., București, 959 pp. [in Romanian]

Bănărescu P (1993) Considerations on the threatened freshwater fishes of Europe. Ocrotirea Naturii şi a Mediului Înconjurător 37(2): 87-98.

Bănărescu P (2005) Pisces. In: Botnariuc N, Tatole V (Eds) Cartea Roșie a vertebratelor din România. Acad. Rom./MNINGA/Curtea Veche ed., pp. 115-155 [in Romanian]

Bănărescu PM, Telecean I, Nalbant TT, Harka Á, Ciobanu M (1999) The fish fauna of the River Someș/Szamos basin. In: Sarkany-Kiss A, Hamar J (Eds) The Someș/Szamos River Valley. A study of the geography, hydrobiology and ecology of the river system and its environment. TISCIA Monography Series, Szolnok-Szeged-Târgu Mureș, 249-268.

Bhat S, Amundsen P-A, Knudsen R, Gjelland KØ, Fevolden SE, Bernatchez L, Præbel K (2014) Speciation reversal in European Whitefish (Coregonus lavaretus (L.)) caused by competitor invasion. PLoS ONE 9(3): e91208. https://doi.org/10.1371/journal.pone.0091208.

Bindea D (2006) Stadiul cercetărilor arheozoologice privind pre- şi protoistoria din Transilvania. Arheologia Moldovei 29: 235-252. [in Romanian]

Bisconti R, Martino G, Chiocchio A, Siclari A, Canestrelli D (2019) Balkan marsh frogs Pelophylax kurtmuelleri (Gayda, 1940) introduced in the Aspromonte National Park, southern Italy. BioInvasions Records 8(1): 26-33.

BirdLife International (2016) Myiagra freycineti. The IUCN Red List of Threatened Species 2016: e.T22707354A94119161. https://dx.doi.org/10.2305/IUCN.UK.2016-3.RLTS. T22707354A94119161.en. 
Boros G, Vitál Z, Moszár A, Borics G, Görgényi J, Vilmos J, Tóth László G, Lehoczky I, Kovács B, Vasas G, Mátyás P, Horváth H, Specziár A (2015) Ecological impacts of filter-feeding Asian carps (Hypophthalmichthys spp.) in Lake Balaton, Hungary. Frontiers in Marine Science, Conference Abstract: XV European Congress of Ichthyology. doi: 10.3389/conf. fmars.2015.03.00019.

Bulat D, Bulat D, Davideanu A, Popescu IE, Davideanu G (2016) Romania - Republic of Moldova joint study concerning the fish fauna in Stânca-Costeşti reservoir. AACL Bioflux 9(3): 550-563.

Bușniță T (1964) Erfahrungen über die Einbürgerung der chinesischen Fische in Rumänien. Wasser und Abwasser 1964: 218-225. [in German]

Cabrera-Guzmán E, Díaz-Paniagua C, Gomez-Mestre I (2019) Invasive mosquitofish (Gambusia holbrooki) affect egg-laying and behaviour of Spanish pygmy newts (Triturus pygmaeus). Amphibia-Reptilia 40: 103-112.

Cadi A, Joly P (2003) Competition for basking places between the endangered European pond turtle (Emys orbicularis galloitalica) and the introduced redeared slider (Trachemys scripta elegans). Canadian Journal of Zoology 81: 1392-1398.

Carpentier A, Gozlan RE, Cucherousset J, Pailisson JM, Martion L (2007) Is topmouth gudgeon Pseudorasbora parva responsible for the decline in sunbleak Leucaspius delineatus populations? Journal of Fish Biology 71 (Supplement D): 274-278.

Călinescu RI (1938) Un peștișor introdus de curând în bălțile noastre: Gambusia affinis. Natura 1(1938): 40-41 [in Romanian]

Ciolac A (2004) Migration of fishes in Romanian Danube river ( $\left.\mathrm{N}^{\circ} 1\right)$. Applied Ecology and Environmental Research 2(1): 143-163.

Cocoș D (2007) Effects of introduced salmonids on amphibian distribution and abundance in Retezat National Park. International Master Programme at the Swedish Biodiversity Centre, Master theses No. 32, Uppsala, ISSN: 1653-834X, https://www.slu.se/globalassets/ ew/org/centrb/cbm/dokument/publikationer-cbm/masteruppsatser/dragoscocosthesis. pdf.

Cogălniceanu D, Băncilă R, Plăiașu R, Samoilă C, Hartel T (2012) Aquatic habitat use by amphibians with specific reference to Rana temporaria at high elevations (Retezat Mountains National Park, Romania). Annales de Limnologie - International Journal of Limnology 48: 355-362.

Copp GH, Bianco PG, Bogutskaya NG, Erős T, Falka I, Ferreira MT, Fox MG, Freyhof J, Gozlan RE, Grabowska J, Kováč V, Moreno-Amich R, Nasek, AM, Peňáz M, Povž M, Przybylski M, Robillard M, Russell IC, Stakenas S, Šume, S, Vila-Gispert A, Wiesne, C (2005) To be, or not to be, a non-native freshwater fish? Journal of Applied Ichthyology 21: 242-262.

Covaciu-Marcov SD, Ferenți S, Sas-Kovács I (2017a) New records of Perccottus glenii Dybowski, 1877 from south-western Romania: invasion in Timiş and Aranca rivers. South Western Journal of Horticulture, Biology and Environment 8(2): 123-128.

Covaciu-Marcov SD, Sas-Kovács I, Cupșa D, Ferenți S (2017b) Perccottus glenii Dybowski, 1877 conquers new waters. First record in a Danube tributary from Oltenia region, southern Romania. Muzeul Olteniei Craiova. Oltenia. Studii şi comunicări. Ştiințele Naturii 33(1): 123-126. 
Covaciu-Marcov SD, Cicort-Lucaciu AȘ, Ferenți S (2018) In water with the enemy! A Lissotriton vulgaris (Amphibia: Salamandridae) paedomorph living together with the non-native fish, Perccottus glenii (Pisces: Odontobutidae) in Romania. Muzeul Olteniei Craiova. Oltenia. Studii şi comunicări. Ştiințele Naturii 34(1): 139-144.

Crenshaw JW (1965) Serum protein variation in an interspecific hybrid swarm of turtles of the genus Pseudemys. Evolution 19: 1-15.

Csaba D, Gabor O, Popescu V, Moldovan C, Hamchevici C, Soare F, Iliescu Ș, Slăvescu E, Gheorghiu I, Chiriac G, Enache R, Nistor C (2011) Sinteza calității apelor din România în anul 2010. http://apepaduri.gov.ro/wp-content/uploads/2014/07/Sinteza-2010.pdf (Dead link, 25.06.2021; text moved to - https://vdocuments.mx/sinteza-calitaii-apelordin-romania-in-anul-2010.html) [in Romanian]

Decei P (1981) Lacuri de munte. Drumeție și pescuit. Ed. Sport-Turism, București, 300 pp. [in Romanian]

Demeter L, Mori C (2004) Spatial distribution and habitat characteristics of Chirocephalus diaphanus (Branchiopoda: Anostraca) in the Retezat National Park (Southern Carpathians, Romania). Biota 5(1-2): 11-23.

Didenko AV, Kruzhylina SV (2015) Trophic interaction between topmouth gudgeon (Pseudorasbora parva) and the co-occurring species during summer in the Dniprodzerzhynsk reservoir. Knowledge and Management of Aquatic Ecosystems 416(13), doi: 10.1051/kmae/2015009 (https://www.kmae-journal.org/articles/kmae/ pdf/2015/01/kmae150014.pdf).

Dimancea N (2013) Note upon the presence of Trachemys scripta elegans (Reptilia) in Oradea city, western Romania. Herpetologica Romanica 7: 41-47.

Dudu A, Popa O, Georgescu SE, Dinischiotu A, Costache M (2010) Molecular analysis of Romanian salmonid species based on $16 \mathrm{~S}$ rRNA and 12S rRNA sequences. Archiva Zootechnica 13(3): 30-40.

Dufresnes C, Denoël M, Di Santo L, Dubey S (2017) Multiple uprising invasions of Pelophylax water frogs, potentially inducing a new hybridogenetic complex. Scientific Reports 7(1): 6506.

Ennen JR, Lovich JE, Kreiser BR, Selman W, Qualls CP (2010) Genetic and morphological variation between populations of the Pascagoula Map Turtle (Graptemys gibbonsi) in the Pearl and Pascagoula rivers with description of a new species. Chelonian Conservation and Biology 9(1): 98-113.

Farkas B, Ziegler T, Pham CT, Ong AV, Fritz U (2019) A new species of Pelodiscus from northeastern Indochina (Testudines, Trionychidae). ZooKeys 824: 71-86.

Freedberg S, Myers EM (2012) Cytonuclear equilibrium following interspecific introgression in a turtle lacking sex chromosomes. Biological Journal of the Linnean Society 106: 405-417.

Fricke R, Eschmeyer WN, van der Laan R (Eds) (2021) Eschmeyer's Catalog Of Fishes: Classification. (http://www.calacademy.org/scientists/catalog-of-fishes-classification/). Electronic version accessed 12.01.2021.

Fritz U, Gong S, Auer M, Kuchling G, Schneeweiss N, Hundsdörfer AK (2010) The world's economically most important chelonians represent a diverse species complex (Testudines: Trionychidae: Pelodiscus). Organisms, Diversity \& Evolution 10: 227-242. 
Froese R Pauly D (Eds) (2019) FishBase. World Wide Web electronic publication. www. fishbase.org, version (12/2019).

Frost DR (2020) Amphibian Species of the World: an Online Reference. Version 6.1 (01.10.2020). Electronic Database accessible at https://amphibiansoftheworld.amnh. org/index.php. American Museum of Natural History, New York, USA. doi.org/10.5531/ db.vz.0001.

Gavriloaie I-C (2007) Survey on the alien freshwater fish species entered into Romania's fauna. Acta Ichthyologica Romanica 2: 69-78.

Gavriloaie I-C (2008) Contributions to the knowledge of Bucharest city ichthyofauna. AACL Bioflux 1: 21-26.

Gavriloaie IC, Berkesy C (2010) Review concerning the native and alien fish species in thermal lake Pețea (Băile 1 Mai, Bihor, Romania). Complexul Muzeal Bistrița-Năsăud, Studii şi Cercetări, Biologie 15: 91-98.

Gavriloaie IC, Berkesy C, Elekes T (2010) Noi contribuții la cunoaşterea ihtiofaunei pârâului şi lacului termal Pețea, Băile 1 Mai, (Bihor, Romania). Ecoterra 24: 24-27 [in Romanian]

Gavriloaie C, Berkesy C (2013) Specii americane de peşti dulcicoli introduce în fauna ihtiologică a României. Ecoterra 37: 51-60 [in Romanian]

Gavriloaie C, Berkesy C, Berkesy L (2015) Some remarks concerning the Asian fish species from Romanian waters. Complexul Muzeal Bistrița-Năsăud, Studii şi Cercetări, Biologie 20: 63-68.

Gavriloaie C, Chişamera G (2005) Note on the occurrence of the blunt-toothed African catfish Clarias ngamensis Castelnau 1861 (Pisces, Clariidae) in Romania. Travaux du Museum National d'Histoire Naturelle "Grigore Antipa" 48: 309-315.

Gavriloaie C, Chişamera G, Stan N, Crăciun N, Petrovici D (2003) Speciile străine de pești introduce în ihtiofauna României. Complexul Muzeal de Științele Naturii „Ion Borcea”, Bacău, Studii şi comunicări, 2000-2003: 207-209 [in Romanian]

Gherghel I, Tedrow R (2019) Manmade structures are used by an invasive species to colonize new territory across a fragmented landscape. Acta Oecologica 101: 103479.

Giurcă R, Angelescu N (1971) Considerații privind biologia și aria de răspîndire geografică a cyprinidului Pseudorasbora parva (Schlegel) în apele României. Buletinul de Cercetări Piscicole 30: 99-109 [in Romanian]

Gozlan RE, Andreou D, Asaeda T, Beyer K, Bouhadad R, Burnard D, Caiola N, Cakic P, Djikanovic V, Esmaeili HR, Falka I, Golicher D, Harka A, Jeney G, Kováč V, Musil J, Nocita A, Povz M, Poulet N, Virbickas T, Wolter C, Tarkan AS, Tricarico, E, Trichkova T, Verreycken H, Witkowski A, Zhang C, Zweimueller I, Britton JR (2010) Pan-continental invasion of Pseudorasbora parva: towards a better understanding of freshwater fish invasions. Fish and Fisheries 11: 315-340.

Hansen MM, Fraser DJ, Als TD, Mensberg K-LD (2008) Reproductive isolation, evolutionary distinctiveness and setting conservation priorities: The case of European lake whitefish and the endangered North Sea houting (Coregonus spp.). BMC Evolutionary Biology 8(1): 137. http://www.biomedcentral.com/1471-2148/8/137. 
Harka Á, Szepesi Zs (2016) The successful establishment of Eastern mosquitofish (Gambusia holbrooki Girard, 1859) in the River Zagyva (water system of the River Tisza, Hungary). Pisces Hungarici 10: 85-87.

Hartel T, Nemes S, Cogălniceanu D, Öllerer K, Schweiger O, Moga C-I, Demeter L (2007) The effect of fish and aquatic habitat complexity on amphibians. Hydrobiologia 583(1): $173-182$.

Hegyeli Zs (2007) Studiul ihtiofaunistic al brațelor moarte ale râurilor Olt şi Râul Negru din județul Covasna. Migrans (Milvus Group) 9(1-2): 10-12 [in Romanian]

Helfenberger N (2001) Phylogenetic relationships of old world ratsnakes based on visceral organ topography, osteology, and allozyme variation. Russian Journal of Herpetology 8 (suppl.): 1-64.

Herczeg D, Vörös J, Christiansen DG, Benovics M, Mikulíček P (2016) Taxonomic composition and ploidy level among European water frogs (Anura: Ranidae: Pelophylax) in eastern Hungary. Journal of Zoological Systematics and Evolutionary Research 55(2): 129-137. Hodson RG (1989) Hybrid striped bass biology and life history. SRAC Publication 300: 1-3. Hotz H, Beerli P, Uzzel T, Guex G-D, Pruvost NBM, Schreiber R, Plötner J (2013) Balancing a Cline by Influx of Migrants: A Genetic Transition in Water Frogs of Eastern Greece. Journal of Heredity 104(1): 57-71.

Hunter ME, Johnson NA, Smith BJ, Davis MC, Butterfield JSS, Snow RW, Hart KM (2018) Cytonuclear discordance in the Florida Everglades invasive Burmese python (Python bivittatus) population reveals possible hybridization with the Indian python (P. molurus). Ecology and Evolution 8(17): 9034-9047.

Iacob M, Petrescu-Mag IV (2008) Inventarul speciilor non-native de pești din apele dulci ale României. Ed. Bioflux, Cluj-Napoca, 89 pp. [in Romanian]

Iftime A (2010) Probleme taxonomice ale unor specii de animale Natura 2000: Reptilia. In: Tatole V (Ed.): Managementul şi monitoringul speciilor de animale Natura 2000 din România. Ghid metodologic. MNINGA/A.S.A. S.C. publ., București, p. 16-20 [in Romanian]

Iftime A, Iftime O (2011) Triturus cristatus (Caudata: Salamandridae) feeds upon dead fishes. Salamandra 47(1): 43-44.

Imecs I, Nagy AA, Demeter L, Ujvári K-R (2014) The fish fauna of the Ciuc Depression (Harghita County, Transylvania, Romania)/A Csíkimedence halfaunája (Hargita megye, Erdély, Románia). Pisces Hungarici 8: 69-76.

Imecs I, Nagy AA (2016) Data concerning the fish fauna of the Moldova river based on surveys of ROSCI0321, ROSCI0365, ROSCI0363, ROSCI0364 Natura 2000 Sites. Analele Științifice ale Universității „Alexandru Ioan Cuza” din Iași, s. Biologie animală 62: 89-104.

IUCN (2017) Invasive alien species and climate change. https://www.iucn.org/sites/dev/files/ ias_and_climate_change_issues_brief_final.pdf.

Jankovic D (1998) Natural reproduction by Asiatic herbivorous fishes in the Yugoslav section of the River Danube. Italian Journal of Zoology 65, suppl.: 227-228.

Jarić I, Bronzi P, Cvijanović G, Lenhardt M, Smederevac-Lalić M, Gessner J (2019) Paddlefish (Polyodon spathula) in Europe: An aquaculture species and a potential invader. Jounal of Applied Ichthyology 35(1): 267-274. 
Jeschke JM, Strayer DL (2005) Invasion success of vertebrates in Europe and North America. Proceedings of the National Academy of Sciences of the United States of America 102(20): 7198-7202.

Khudyi O, Khuda L (2013) The distribution of alien fish species in the waters of northern Bukovina and northern Bessarabia (Ukraine). In: Dgebuadze YuYu, Slynko YuV, Krylov AV (Eds) The IV International symposium "Invasion of alien species in Holarctic" (Sept. 22-23, Borok, Russia). Programme and book of abstracts. I.D. Papanin Institute for Biology of Inland Waters Russian Academy of Sciences, A.N. Severtsov Institute of Ecology and Evolution Russian Academy of Sciences. Publisher's bureau "Filigran”, Yaroslavl, 87.

Kizak V, Güner Y (2014) First record of F2 hybrid striped bass (Morone chrysops o x Morone saxatilis $\mathrm{O}^{7} \mathrm{x}$ Morone chrysops $\mathrm{O} \times \mathrm{x}$ Morone saxatilis $\mathrm{O}^{7}$ ) in Kemer Dam Lake. Turkish Journal of Zoology 38(5): 637-641.

Kleewein A (2015) Interactions between Emys orbicularis and allochthonous turtles of the family Emydidae at basking places. Hyla 1/2015: 11-17.

Knytl M, Kalous L, Rylková K, Choleva L, Merilä J, Ráb P (2018) Morphologically indistinguishable hybrid Carassius female with 156 chromosomes: A threat for the threatened crucian carp, C. carassius, L. PLoS ONE 13(1): e0190924. https://doi. org/10.1371/journal.pone.0190924.

Kokodiy SV (2018) Age and growth comparison of diploid and triploid species of Crucian carps (Cypriniformes, Cyprinidae) in the water bodies of the Dnipro basin. Vestnik Zoologii 52(1): 75-84.

Kolenda K, Pietras-Lebioda A, Hofman S, Ogielska M, Pabjian M (2017) Preliminary genetic data suggest the occurrence of the Balkan water frog, Pelophylax kurtmuelleri, in southwestern Poland. Amphibia-Reptilia 38(2): 187-196.

Konečný A, Popa OP, Bartáková V, Douda K, Bryja J, Smith C, Popa LO, Reichard M (2018) Modelling the invasion history of Sinanodonta woodiana in Europe: Tracking the routes of a sedentary aquatic invader with mobile parasitic larvae. Evolutionary Applications 11: 1975-1989.

Kostakiozi P, Jablonsk, D, Ilgaz Ç, Kumlutaș Y, Avci A, Meiri S, Itescu Y, Kukushkin O, Gvoždík V, Scillitani G, Roussos SA, Jandzik D, Kasapidis P, Lymberakis P, Poulakakis N (2018) Multilocus phylogeny and coalescent species delimitation in Kotschy's gecko, Mediodactylus kotschyi: Hidden diversity and cryptic species. Molecular Phylogenetics and Evolution 125: 177-187.

Koynova T, Doichev D, Natchev N (2020) New data on the distribution of the Bulgarian Benttoed Gecko (Mediodactylus danilewskii Strauch, 1887) in Shumen town (NE Bulgaria). Biharean Biologist 14(2): e202302.

Kvach Y, Karavanskyi Y, Tkachenko P, Zamorov V (2021) First record of the invasive Chinese sleeper, PERCCOTTUS GLENII Dybowski, 1877 (Gobiiformes: Odontobutidae) in the Black Sea. BioInvasions Records, 10: (2): 411-418.

Landeka N, Podnar M, Jelić D (2015) New data on the taxonomic status and distribution of Gambusia sp. in Croatia and Bosnia and Herzegovina. Periodicum Biologorum 117(3): 415-424. 
Lee DS (2012) The Future of Map Turtles: Will the Mutts Take Over? Bulletin of the Chicago Herpetological Society 47(5): 57-62.

Lehtonen H (2002) Alien freshwater fishes of Europe. In: Leppakoski E, Gollasch S, Olenin S (Eds) Invasive Aquatic Species of Europe. Distribution, impacts and management. Kluwer Academic Publishers, pp. 153-161.

Lenhardt M, Markovic G, Hegedis A, Maletin S, Cirkovic M, Markovic Z (2011) Non-native and translocated fish species in Serbia and their impact on the native ichthyofauna. Reviews in Fish Biology and Fisheries 21(3): 407-421.

Lenk P, Joger U, Wink M (2001) Phylogenetic relationships among European ratsnakes of the genus Elaphe Fitzinger based on mitochondrial DNA sequence comparisons. Amphibia-Reptilia 22: 329-339.

Li XY, Liu XL, Zhu YJ, Zhang J, Ding M, Wang MT, Wang ZW, Li Z, Zhang XJ, Zhou L, Gui JF (2018) Origin and transition of sex determination mechanisms in a gynogenetic hexaploid fish. Heredity 121: 64-74

Lindeman PV (2013) The Map Turtle and Sawback atlas: Ecology, evolution, distribution, and conservation. University of Oklahoma Press (Norman, OK), 460 pp.

Litvinchuk SN, Ivanov AYu, Lukonina SA, Ermakov OA (2020) A record of alien Pelophylax species and widespread mitochondrial DNA transfer in Kaliningradskaya Oblast' (the Baltic coast, Russia). BioInvasions Records 9(3): 599-617.

Liu XL, Jiang FF, Wang ZW, Li X-Y, Li Z, Zhang X-J, Chen F, Mao J-F, Li Z, Gui J-F (2017) Wider geographic distribution and higher diversity of hexaploids than tetraploids in Carassius species complex reveal recurrent polyploidy effects on adaptive evolution. Scientific Reports, 7: 5395. https://doi.org/10.1038/s41598-017-05731-0.

Liu Q, Liu J, Liang Q, Qi Y, Tao M, Zhang C, Qin Q, Zhao R, Chen B, Liu S (2019) A hybrid lineage derived from hybridization of Carassius cuvieri and Carassius auratus red var. and a new type of improved fish obtained by back-crossing. Aquaculture 505: 173-182.

Lojkásek B, Lusk S (2018) Non-native fish species in River Odra and Morava basins in the Czech Republic. Acta Musei Silesiae Scientiae Naturales 67: 81-96.

Lozinsky RL (2009) Reprezentanți ai familiei Belontiidae (Teleostei, Anabantoidei) în apele termale bihorene - supraviețuirea lor în anotimpul rece. Ecoterra 20:32-33 [in Romanian]

Ludwig A, Lippold S, Debus L, Reinarzt R (2009) First evidence of hybridization between endangered sterlets (Acipenser ruthenus) and exotic Siberian sturgeons (Acipenser baerii) in the Danube River. Biological Invasions 11(3): 753-760.

Lukanov S, Tzankov S, Simeonovska-Nikolova D (2015) A comparative study of the mating call of Pelophylax ridibundus and Pelophylax kurtmuelleri (Anura: Ranidae) from syntopic and allotropic populations. Journal of Natural History 49(5-8): 257-272.

Luo J, Gao Y, Ma W, Bi X-Y, Wang S-Y, Wang J, Wang Y-Q, Chai J, Du R, Wu S-F, Meyer A, Zan R-G, Xiao H, Murphy RW, Zhang Y-P (2014) Tempo and mode of recurrent polyploidization in the Carassius auratus species complex (Cypriniformes, Cyprinidae). Heredity 112: 415-427.

Macchi S, Balzarini LLM, Scali S, Martinoli A, Tosi G (2008) Spatial competition for basking sites between the exotic slider Trachemys scripta and the European Pond Turtle Emys 
orbicularis. In: Corti C (Ed.) Herpetologia Sardiniae. Societas Herpetologica Italica/ Edizioni Belvedere, Latina, "Le Scienze" (8): 338-340.

Malbrouck C, Mergen P, Micha J-C (2005) Growth and diet of introduced coregonid fish Coregonus peled (Gmelin) and Coregonus lavaretus (L.) in two Belgian reservoir lakes. Applied Ecology and Environmental Research 4(1): 27-44.

Manea GI (1985) Aclimatizarea de noi pești și alte organisme acvatice. Ed. Ceres, București, 160 pp. [in Romanian]

Marosi BA Kiemnec-Tibursky KM, Ghira IV, Sos T, Popescu O (2014) Identification and characterization of major histocompatibility complex class IIB alleles from three species of European ranid frogs. Molecular Biology Research Communications 3(4): 215-222.

Matei I, Tudor M (2014) Competition on microhabitat quality between the pond slider (Trachemys scripta) and European pond turtle (Emys orbicularis). A case study in two quasi isolated water bodies in Constanta city. In: Popa LO, Adam C, Chișamera G, Iorgu E, Murariu D, Popa, OP (Eds) International Zoological Congress of "Grigore Antipa" Museum, 19 - 22 November 2014, Bucharest - Romania, Book of Abstracts, 188.

Mezhzherin SV, Kokodyi SV, Pukhtaevich PP, Kulish AV (2017) Peculiarities of population structure and hybridization of the genus Carassius (Cypriniformes, Cyprinidae) in Polyssia (Northern Ukraine). Vestnik Zoologii 51(2): 167-174.

Mezhzherin SV, Pukhtaevich PP, Kokodyi SV (2020) The polyclonal structure of unisexual Prussian Carp (Carassius gibelio (Bloch, 1782)) settlements in Northern Ukraine: comparison analysis of allozyme markers and chromosome numbers. Cytology and Genetics 54: 55-62.

Mitchell SM, Muehlbauer LK, Freedberg S (2016) Nuclear introgression without mitochondrial introgression in two turtle species exhibiting sex-specific trophic differentiation. Ecology and Evolution 6(10): 3280-3288.

Moshu JA, Davideanu GG, Cebanu A (2006) Elements of the Ichthyofauna diversity of Prut River basin. Acta Ichtiologica Romanica 1: 171-184.

Movchan YuV, Talabishka EM, Velikopolskiy IJ (2014) Fishes of the genus Ameiurus (Ictaluridae, Siluriformes) in the Transcarpathian water bodies. Vestnik Zoologii 48(2): 149-156.

Müller T, Bernáth G, Horváth Á, Várkonyi L, Grigoraș G, Gagiu A, Urbány, B, Żarski D, Freyhof J, Cameron T (2018) Artificial propagation of the endangered Rumanian endemic warm water rudd (Scardinius racovitzai Müller 1958, Cyprinidae, Cypriniformes) for conservation needs. Egyptian Journal of Aquatic Research 44(3): 245-249.

Na-Nakorn U, Brummett RE (2009) Use and exchange of aquatic genetic resources for food and aquaculture: Clarias catfish. Reviews in Aquaculture 1(3-4): 241-223.

Nalbant T (2003) Checklist of the fishes of Romania. Part one: freshwater and brackishwater fishes. Studii şi Cercetări Ştiințifice, Biologie, Bacău, serie nouă, 8: 122-127.

Nalbant T, Battes K, Pricope F, Ureche D (2004) First record of the Amur Sleeper Perccottus glenii (Pisces: Perciformes: Odontobutidae) in Romania. Travaux du Museum National d'Histoire Naturelle „Grigore Antipa” 47: 279-284.

Năstase A (2007) First record of amur sleeper Perccottus glenii (Perciformes, Odontobutidae) in the Danube Delta (Dobrogea, Romania). Acta Ichtiologica Romanica 2: 167-174. 
Năstase A, Cernișencu I, Năvodaru I (2019) A decade (2007-2017) from first record of the invasion in Danube Delta (Romania) by the nonnative Chinese sleeper (Perccottus glenii, Dybowsky 1877) species in North of Balkan area. Journal of Environmental Protection and Ecology 20(4): 1796-1805.

Năvodaru I, Buijse AD, Staraș M (2002) Effects of hydrology and water quality on the fish community in Danube delta lakes. International Review of Hydrobiology 87: 329-348.

Nistor CE, Pagu IB, Simeanu C, Păsărin B (2012) Analysis of some morphological characteristics of Salvelinus fontinalis trout breed farmed in salmonid exploatations from Neamț and Suceava counties. University of Agricultural Sciences and Veterinary Medicine Iași, Lucrări Ştiințifice - Seria Zootehnie 58: 225-229.

Nowak M, Koščo J, Szczerbik P, Mierzwa D, Popek W (2010) When did the black bullhead, Ameiurus melas (Teleostei: Ictaluridae), arrive to Poland? Archives of Polish Fisheries 18(3): 183-186.

Oțel V (2007) Atlasul peștilor din Rezervația Biosferei Delta Dunării. Ed. Centrul de Informare Tehnologică Delta Dunării, Tulcea, 481 pp. [in Romanian]

Oțel V (2019) Is Carassius gibelio (Pisces, Cyprinidae) a native or non-native species in Romania? Scientific Annals of the Danube Delta Institute 24: 77-84 [in Romanian]

Østbye K, Bernatchez L, Naesje TF, Himberg K-JM, Hindar K (2005) Evolutionary history of the European whitefish Coregonus lavaretus (L.) species complex as inferred from mtDNA phylogeography and gill-raker numbers. Molecular Ecology 14(14): 4371-4387.

Pakosta T, Vetešník L, Šimková A (2018) A long temporal study of parasitism in asexual-sexual populations of Carassius gibelio: does the parasite infection support coevolutionary Red Queen dynamics? BioMed Research International, vol. 2018, Article ID 6983740, 10 pp. https://doi.org/10.1155/2018/6983740.

Papadopol CN, Curlișcă A, Stan G (2012) Observations regarding the stocking solutions into aquatic enclosures, under controlled conditions, while preserving the balance between ichthyological livestock and a small population of Pelecanus onocrotalus. Muzeul Olteniei Craiova. Oltenia. Studii și comunicări. Științele Naturii 28(2): 119-122.

Papežík P, Kubala M, Jablonski D, Doležálková-Kaštánková M, Choleva L, Benovics M, Mikulíček P (2021) Morphological differentiation of endemic water frogs (Ranidae: Pelophylax) from the southwestern Balkans. Salamandra 57(1): 105-123.

Păpuc T, Ladoși D, Boaru A (2018) The black bullhead (Ameiurus melas, Rafinesque 1820) - a new invasive fish species in Someș river, Romania. ELBA Bioflux 10(1): 18-24.

Parham JF, Papenfuss TJ, Sellas AB, Stuart BL, Simison WB (2020) Genetic variation and admixture of red-eared sliders (Trachemys scripta elegans) in the USA. Molecular Phylogenetics and Evolution, 145: 106722.

Pérez-Santigosa N, Florencio M, Hidalgo-Vila J, Díaz-Paniagua C (2011) Does the exotic invader turtle, Trachemys scripta elegans, compete for food with coexisting native turtles? Amphibia-Reptilia 32(2): 167-175.

Piria M, Simonović P, Kalogianni E, Vardakas L, Koutsikos N, Zanella D, Ristovska M, Apostolou A, Adrović A, Mrdak D, Tarkan AS, Milošević D, Zanella LN, Bakiu R, Ekmekçi FG, Povž M, Korro K, Nikolić V, Škrijelj R, Kostov V, Gregori A, Joy MK (2017) Alien 
freshwater fish species in the Balkans-Vectors and pathways of introduction. Fish and Fisheries 2017: 1-32, https://doi.org/10.1111/faf.12242.

Piria M Jelkić D, Gavrilović A, Špelić I, Opačak A, Ozimec, S (2019) First record of North African catfish (Clarias gariepinus) in Croatian inland waters. Frontiers in Marine Science, Conference Abstract: XVI European Congress of Ichthyology. doi: 10.3389/ conf.fmars.2019.07.00142.

Plötner J, Uzzell T, Beerli P, Spolsky C, Ohst T, Litvinchuk SN, Guex G-D, Reyer H-U, Hotz $\mathrm{H}$ (2008) Widespread unidirectional transfer of mitochondrial DNA: a case in western Palaearctic water frogs. Journal of Evolutionary Biology 21(3): 668-681.

Plötner J, Uzzell T, Beerli P, Akin Ç, Bilgin CC, Haefeli C, Ohst T, Köhler F, Schreiber R, Guex G-D, Litvinchuk SN, Westaway R, Reyer H-U, Pruvost N, Hotz H (2010) Genetic divergence and evolution of reproductive isolation in Eastern Mediterranean water frogs. In: Glaubrecht M, Schneider H (Ed.) Evolution in action, Springer-Verlag (BerlinHeidelberg), pp. 373-403.

Polačik M, Trichkova T, Janáč M, Vassilev M, Jurajda P (2008) The ichthyofauna of the shoreline zone in the longitudinal profile of the Danube River, Bulgaria. Acta Zoologica Bulgarica 60(1): 77-88.

Popa G-O, Dudu A, Bănăduc D, Curtean-Bănăduc A, Barbălată T, Burcea A, (Gune) Florescu IE, Georgescu SE, Costache M (2017) Use of DNA barcoding in the assignment of commercially valuable fish species from Romania. Aquatic Living Resources 30: 20, https://doi.org/10.1051/alr/2017018.

Popa LO Popa OP, Pisică EI, Iftime A, Matacă S, Diaconu F, Murariu D (2006) The first record of Perccottus glenii Dybowski, 1877 (Pisces: Odontobutidae) and Ameiurus melas Rafinesque, 1820 (Pisces: Ictaluridae) from the Romanian sector of the Danube. Travaux du Muséum National d'Histoire Naturelle “Grigore Antipa” 49: 323-329.

Popa OP, Popa LO, Krapal AM, Murariu D, Iorgu EI, Costache M (2011) Sinanodonta woodiana (Mollusca: Bivalvia: Unionidae): isolation and characterization of the first microsatellite markers. International Journal of Molecular Sciences 12(8): 5255-5260.

Popovici M, Jianu LD (2006) Mlaştina Hergheliei (Mangalia, jud. Constanța) - potențială arie naturală protejată pentru conservarea avifaunistică. Delta Dunării 3: 71-84.

Povž M (2017) Non-native freshwater fishes in Slovenia. Acta Zoologica Bulgarica, Suppl. 9: $105-110$.

Przybył A, Przybylski M, Spóz A, Juchno D, Szabelska A, Kowalewska K, Boroń A (2020) Sex, size and ploidy ratios of Carassius gibelio from Poland. Aquatic Invasions 15(2): 335-354.

Qin Q, Wang J, Hu M, Huang S, Liu S (2016) Autotriploid origin of Carassius auratus as revealed by chromosomal locus analysis. Science China, Life Sciences 59(6): 622-626.

Reichard M, Douda K, Przybyłsk, M, Popa OP, Karbanová E, Matasová K, Rylková K, Polačik M, Blažek R, Smith C (2015) Population-specific responses to an invasive species. Proceedings of the Royal Society B 282: 20151063. http://dx.doi.org/10.1098/ rspb.2015.1063.

Reshetnikov AN (2013) Spatio-temporal dynamics of the expansion of rotan Perccottus glenii from West-Ukrainian centre of distribution and consequences for European freshwater ecosystems. Aquatic Invasions 8(2): 193-206. 
Rhodin AGJ, Iverson JB, Bour R, Fritz U, Georges A, Bradley Shaffer H, Van Dijk PP (2017) Turtles of the World. Annotated checklist and atlas of taxonomy, synonymy, distribution, and conservation status (8th ed.). Chelonian Research Monographs 7: 1-292.

Romanian Environment Ministry (MMSC/MMAP) (2016) Planul de management al Parcului Național Cheile Bicazului - Hășmaș. http://www.mmediu.ro/app/webroot/uploads/ files/2016-06-16_Plan_de_management_PNCB-H.pdf [in Romanian]

Rosecchi E, Crivelli A, Catsadorakis G (1993) The establishment and impact of Pseudorasbora parva, an exotic fish species introduced into Lake Mikri Prespa (north-western Greece). Aquatic Conservation: Marine and Freshwater Ecosystems 3: 223-231.

Roy D, Alderman D, Anastasiu P, Arianoutsou M, Augustin S, Bacher S, Başnou C, Beisel J, Bertolino S, Bonesi L, Bretagnolle F, Chapuis JL, Chauvel B, Chiron F, Clergeau P, Cooper J, Cunha T, Delipetrou P, Desprez-Loustau M, Détaint M, Devin S, Didžiulis V, Essl F, Galil BS, Genovesi P, Gherardi F, Gollasch S, Hejda M, Hulme PE, Josefsson M, Kark S, Kauhala K, Kenis M, Klotz S, Kobelt M, Kühn I, Lambdon PW, Larsson T, LopezVaamonde C, Lorvelec O, Marchante H, Minchin D, Nentwig W, Occhipinti-Ambrogi A, Olenin S, Olenina I, Ovcharenko I, Panov VE, Pascal M, Perg, J, Perglová I, Pino J, Pyšek P, Rabitsch W, Rasplus J, Rathod B, Roques A, Roy H, Sauvard D, Scalera R, Shiganova TA, Shirley S, Shwartz, A, Solarz W, Vilà M, Winter M, Yésou P, Zaiko A, Adriaens T, Desmet P, Reyserhove L (2020) DAISIE - Inventory of alien invasive species in Europe. Version 1.7. Research Institute for Nature and Forest (INBO). Checklist dataset https:// doi.org/10.15468/ybwd3x accessed via GBIF.org on 2021-03-17.

Rutyaková J, Biskup R, Harant R, Šlechta V, Koščo J (2012) Ameiurus melas (black bullhead): Morphological characteristics of new introduced species and its comparison with Ameiurus nebulosus (brown bullhead). Reviews in Fish Biology and Fisheries 23(1): 51-68. Rylková K, Kalous L, Bohlen J, Lamatsch DJ, Petrtýl M (2013) Phylogeny and biogeographic history of the cyprinid fish genus Carassius (Teleostei: Cyprinidae) with focus on natural and anthropogenic arrivals in Europe. Aquaculture 380-383: 13-20.

Salonen E, Mutenia A (2007) Alien fish species in northernmost Finland. Finnish Game and Fisheries Research Institute, Helsinki.

Sava A, Uiuiu A, Vădean C, Mireșan V, Cocan D (2012) Aclimatizarea păstrăvului arctic (Salvelinus alpinus) în păstrăvăria Trecătoarea Ursului, jud. Brașov. Simpozionul studențesc USAMV Cluj-Napoca, 2012, http://www.usamvcluj.ro/simpo_stud/files/ 2012/3.Facultatea\%20de\%20Zootehnie\%20si\%20Biotehnologii/10.Zootehnie\%20si \%20piscicultura/Sava\%20Alexandru.pdf.

Semlitsch RD, Peterman WE, Anderson TL, Drake DL, Ousterhout BH (2015) Intermediate pond sizes contain the highest density, richness, and diversity of pond-breeding amphibians. PLOS ONE 10(4): e0123055. https://doi.org/10.1371/journal.pone.0123055. Sendek DS (2004) The origin of sympatric forms of European whitefish (Coregonus lavaretus (L.) in Lake Ladoga based on comparative genetic analysis of populations in North-West Russia. Annales Zoologici Fennici 41: 25-39.

Simeanu C, Păsărin B, Simeanu D, Grădinaru AC (2015) Polyodon spathula - a review on its biodiversity, meat quality, and environmental impact in Romania. AACL Bioflux 8(6): 952-959. 
Simonović P, Marić S, Nikolić V (2006) Occurrence of paddlefish Polyodon spathula (Walbaum, 1792) in the Serbian part of the lower River Danube. Aquatic Invasions 1(3): 183-185.

Skorić S, Cvijanović G, Kohlmann K, Hegediš A, Jarić I, Lenhardt M (2013) First record of a hybrid striped bass (Morone saxatilis X Morone chrysops) in the Danube river. Journal of Applied Ichthyology 29: 668-670.

Soes DM, Leuwen RSEW, Matthews J, Broeckx PB, Haenen OLM, Engelsma MY (2011) A risk analysis of bigheaded carp (Hypophthalmichthys sp.) in the Netherlands. Bureau Waardenburg bv.

Sos T (2007) Emys orbicularis vs Trachemys scripta elegans. Migrans (Milvus Group) 9(1-2): $7-9$.

Sos T (2009) The European Pond Turtle in Romania. In: Rogner M (Ed.) European Pond Turtle, Emys orbicularis. Chimaira Ed., 207-209.

Speybroeck J, Beukema W, Bok B, Van Der Voort J, Velikov I (2016) Field Guide to the Amphibians and Reptiles of Britain and Europe (British Wildlife Field Guides). Bloomsbury Natural History, London/New York.

Speybroeck J, Beukema W, Dufresnes C, Fritz U, Jablonski D, Lymberakis P, Martínez-Solano I, Razzetti E, Vamberger M, Vences M, Vörös J, Crochet P.-A (2020) Species List of the European Herpetofauna - 2020, update by the Taxonomic Committee of the Societas Europaea Herpetologica. Amphibia-Reptilia 41: 139-189.

Spikmans F, Lemmers P, Op Den Camp HJM, Van Haren E, Kappen F, Blaakmeer A, Van Der Velde G, Van Langevelde F, Leuwen RSEW, Van Alen TA (2020) Impact of the invasive alien topmouth gudgeon (Pseudorasbora parva) and its associated parasite Sphaerothecum destruens on native fish species. Biological Invasions 22: 587-601.

Spinks PQ, Thomson, RC, Pauly GB, Newman CE, Mount G, Bradley Shaffer H (2013) Misleading phylogenetic inferences based on single-exemplar sampling in the turtle genus Pseudemys. Molecular Phylogenetics and Evolution 68: 269-281.

Stănescu SV, Gavriloaie C (2011) Aspecte privind vegetaţia şi fauna râului Colentina pe traseul din municipiul Bucureşti (România). Ecoterra 27: 49-52 [in Romanian]

Stănescu F, Sos T, Samoilă C, Cogălniceanu D (2017) Trachemys scripta in the East and South European Region. A review of the invasion extent. Poster presentation, 7th ESENIAS Workshop with Scientific Conference 'Networking and Regional Cooperation Towards Invasive Alien Species Prevention and Management in Europe, 28-30 March 2017, IBER-BAS, ESENIAS, Sofia, Bulgaria.

Stănescu F, Rozylowicz L, Tudor M, Cogălniceanu D (2020) Alien vertebrates in Romania. Acta Zoologica Bulgarica 72(4): 583-595.

Staraș M, Oțel V (1999) Evidences regarding the natural spawning of the silver carp species (Hypophthalmychthys molitrix Val.) in the Danube river. Analele Științifice ale IDD 7: 183-188.

Telcean I, Cicort-Lucaciu A-Ș (2016) Messages of invasive Perccottus glenii individuals eaten by an Esox lucius from the Danube Delta. Journal of Fisheries 4(3): 435-438.

Telcean IC, Cupșa D, Covaciu-Marcov S-D, Sas I (2005) The fishfauna of the Crişul Repede river and its threatening major factors. Agrártudományi Közlemények, Supplement 2005, Pisces Hungarici 1: 13-19. 
Telcean IC, Cupșa D (2009) The backwaters and drainage canals as natural refuges for the lowland rivers' fishfauna (Someş, Crişuri, and Mureş Rivers - north-western Romania). Biharean Biologist 3(1): 37-44.

Telcean IC, Sas-Kovács I, Covaciu-Marcov S-D (2015) Unusual altitude and habitat for the invasive fish Pseudorasbora parva in the Vâlsan River basin, Romania. Muzeul Olteniei Craiova. Oltenia. Studii şi comunicări. Ştiințele Naturii 31(1): 237-240.

Thomas RB, Jansen KP (2006) Pseudemys floridana - Florida Cooter. In: Meylan PA (Ed.) Biology and conservation of the Florida turtles. Chelonian Research Monographs, 3: $338-347$.

Tzankov N (2007) Balkanski gekon/Balkan gekko. In: Biserkov V (Ed.) Opredelitel na zemnovodnite i vlechugite na Balgaria/A field guide to amphibians and reptiles of Bulgaria. Sofia, Zeleni Balkani/Green Balkans.

Ueda K (2021) iNaturalist Research-grade Observations. iNaturalist.org. Occurrence dataset https://doi.org/10.15468/ab3s5x accessed via GBIF.org on 2021-03-16. https://www.gbif. org/occurrence/2451746018.

Uetz P, Freed P, Hošek J (Eds) (2020) The Reptile Database, http://www.reptile-database.org/ http://reptile-database.reptarium.cz/ accessed 01.10.2020.

Ureche D, Ureche C (2016) Spreading of Perccottus glenii Dybowski 1877 (Perciformes, Odontobutidae) in Romanian basin of the River Siret. In: Sustainable use, protection of animal world and forest management in the context of climate change. Ed. IX, 12-13 octombrie 2016, Chișinău. Chișinău: Institutul de Zoologie, p. 235.

Urošević A, Tomović L, Atić R, Simović A, Džukić G (2016) Alterations in the reptilian fauna of Serbia: Introduction of exotic and anthropogenic range expansion of native species. Herpetozoa 28(3/4): 115-132.

Utiger U, Helfenberger N, Schätti B, Schmidt C, Ruf M, Ziswiler V (2002) Molecular systematics and phylogeny of Old and New World Ratsnakes, Elaphe auct., and related genera (Reptilia, Squamata, Colubridae). Russian Journal of Herpetology 9(2): 105-124.

van der Laan R, Fricke R, Eschmeyer WN (Eds) (2021) Eschmeyer's Catalog of Fishes: Classification (http://www.calacademy.org/scientists/catalog-of-fishes-classification/). Electronic version accessed 02.06. 2021.

Van Zon JCJ (1977) Grass carp (Ctenopharyngodon idella Val.) in Europe. Aquatic Botany 3: 143-155.

Vannini A, Bruni G, Ricciardi G, Platania L, Mori E, Tricarico E (2018) Gambusia holbrooki, the 'tadpolefish': The impact of its predatory behaviour on four protected species of European amphibians. Aquatic Conservation: Marine and Freshwater Ecosystems 2018: 1-9.

Vitál Z, Vilmos J, Specziár A, Moszár A, Lehoczky I, Kovács B, Hliwa P, Boros G (2017) Source of bigheaded carp (Hypophthalmichthys spp.) in Lake Balaton, Hungary: natural recruitment or continuous escapement from aquaculture? Inland Waters 7(2): 218-226.

Vogt RC (1993) Systematics of the False Map Turtles (Graptemys pseudogeographica complex: Reptilia, Testudines, Emydidae). Annals of Carnegie Museum 62(1): 1-46.

Vogt RC (2018) Graptemys ouachitensis Cagle 1953 - Ouachita Map Turtle. In: Rhodin AGJ, Iverson JB, van Dijk PP, Buhlmann KA, Pritchard PCH, Mittermeier RA (Eds) Conservation Biology of Freshwater Turtles and Tortoises: A Compilation Project of 
the IUCN/SSC Tortoise and Freshwater Turtle Specialist Group. Chelonian Research Monographs 5(11): 103.1-13. doi: 10.3854/crm.5.103.ouachitensis.v1.2018; www. iucn-tftsg.org/cbftt/.

Vörös L (2000) Effective control of nuisance cyanobacterial blooms by biomanipulation. Egyptian Journal of Phycology 1: 267-277.

Vucić M, Jelić D, Klobučar GIV, Prkljačić B, Jelić M (2018) Molecular identification of species and hybrids of water frogs (genus Pelophylax) from Lake Skadar, Southeast Adriatic drainages (Amphibia: Ranidae). Salamandra 54(2): 147-157.

Weiperth A, Staszny Á, Ferincz Á (2013) Idegenhonos halfajok megjelenése és terjedése a Duna magyarországi szakaszán - Történeti áttekintés. Pisces Hungarici 7: 103-112 [in Hungarian]

Wilhelm S (2013) A törpeharcsa. Societatea Muzeului Ardelean, Cluj-Napoca, 120 pp. [in Hungarian]

Williamson M, Fitter A (1996) The varying success of invaders. Ecology 77(6): 1661-1666. Williot P, Chebanov M (2018) Controlled reproduction of farmed Siberian sturgeon. In: Williot P, Nonnotte G, Chebanov M (Eds) The Siberian Sturgeon (Acipenser baerii, Brandt, 1869), Volume 2 - Farming, Springer, pp. 13-48.

Wyatt KB, Campos PF, Gilbert MTP, Kolokotronis S-O, Hynes WH, Desalle R, Daszak P, Macphee RDE, Greenwood AD (2008) Historical mammal extinction on Christmas Island (Indian Ocean) correlates with introduced infectious disease. PLoS ONE 3(11): e3602. doi:10.1371/journal.pone.0003602.

WWF Internațional/Programul Dunăre-Carpați (2014) Protejarea sturionilor din Dunăre. Ghid practic pentru agențiile care se ocupă de controlul pescuitului, comerțului cu caviar și al fermelor de sturioni. [in Romanian]

Xiao J, Zou T, Chen Y, Chen L, Liu S, Tao M, Zhang C, Zhao R, Zhou Y, Long Y, You C, Yan J, Liu Y (2011) Coexistence of diploid, triploid and tetraploid crucian carp (Carassius auratus) in natural waters. BMC Genetics 12, 20. https://doi.org/10.1186/1471-2156-12-20.

Yankova M (2016) Alien invasive fish species in Bulgarian waters: an overview. International Journal of Fisheries and Aquatic Studies 4(2): 282-290.

Zięba G, Vilizzi L, Copp GH (2019) How likely is Lepomis gibbosus to become invasive in Poland under conditions of climate warming? Acta Ichthyologica et Piscatoria 50(1): $37-51$.

Zorić K, Simonović P, Đikanović V, Marković V, Nikolić V, Simić V, Paunović M (2014) Checklist of non-indigenous fish species of the river Danube. Archives of Biological Sciences 66(2): 629-639.

*** Legea nr. 49 din 2011. Monitorul Oficial al României, an 179(XXIII), nr. 262: 2-12 [in Romanian]

*** Ordonanța de Urgență a Guvernului nr. 57 din 2007. Monitorul Oficial al României, an 175(XIX), nr. 442: 2-12 [in Romanian]

*** Regulamentul (CE) nr. 506/2008 al Comisiei din 6 iunie 2008 de modificare a anexei IV la Regulamentul (CE) nr. 708/2007 al Consiliului privind utilizarea în acvacultură a speciilor exotice și a speciilor absente la nivel local. Jurnalul Oficial al Uniunii Europene, L149 (7.6.2008): 36-37 [in Romanian] 
*** Andy Arif Fishing (2018) Populare Black Bass si Striped Bass pe lacul Tancabesti! https:// www.youtube.com/watch? $\mathrm{v}=$ jwkBKHgeP0A (accessed 25.06.2021).

*** Cioflec V (2013) T,estoasa de Florida. https://fieldherpingromania.wordpress. com/2013/05/01/testoasa-de-florida/ (accessed 25.06.2021) [in Romanian]

*** Cioflec V (2017-2021) Țestoase noi pentru țară. https://fieldherpingromania.wordpress. com/2017/06/01/noi-testoase-problematice/ (accessed 25.06.2021) [in Romanian]

*** Cioflec V (2019a) Prima populație de gecko. https://fieldherpingromania.wordpress. com/2019/09/01/prima-populatie-de-gecko/ (accessed 25.06.2021) [in Romanian]

*** Cioflec V (2019-2020) O nouă șopârlă în România. https://fieldherpingromania.wordpress. com/2019/05/03/o-noua-soparla/ (accessed 25.06.2021) [in Romanian]

*** Cioflec V (2020) Gecko, pandemie și pisici. https://fieldherpingromania.wordpress. com/2020/05/16/gecko-pandemie-si-pisici/ (accessed 25.06.2021) [in Romanian]

*** Brezeanu G (2018) Lacul dragat de la Bucov. https://goo.gl/maps/6C74VofFFFQVy8wy8 (accessed 25.06.2021). [in Romanian]

*** Dynavit Impex (2021). Somn. Somnul African (Clarias). https://dynavit.ro/produs-somn/ (accessed 25.06.2021) [In Romanian]

*** Dragomir G (2021). Povestea șopârlelor gecko, aduse accidental din țări exotice, în bagaje sau tiruri cu marfă, și care s-au adaptat și înmulțit în București și alte mari orașe. https:// life.hotnews.ro/stiri-prin_oras-24814439-povestea-soparlelor-gecko-din-romania.htm (accessed 25.06.2021) [in Romanian]

*** GherlaInfo (2019a) Pește cu dinți ca de om prins pe Someș la Gherla, „E Piranha!”. https:// www.gherlainfo.ro/peste-cu-dinti-ca-de-om-pe-somes-la-gherla-e-piranha-video/ (accessed 25.06.2021) [in Romanian]

*** GherlaInfo (2019b) După șerpi, au apărut pe malul Someșului Mic la Gherla broaște țestoase. Ce ar trebui să faci dacă le întâlnești https://www.gherlainfo.ro/dupa-serpi-auaparut-pe-malul-somesului-mic-la-gherla-broaste-testoase-foto/ (accessed 25.06.2021) [in Romanian]

*** Iazul Bârca (2020) Populare cu 2 familii de buffalo la Iazul Bârca. https://www.facebook. $\mathrm{com} /$ watch/?v=1477742622393521. 34 (accessed 25.06.2021) [in Romanian]

*** Panaitescu D (2019a) Populație de gecko în București și... o invitație la citizen science. https://www.dorupanaitescu.ro/noua-populatie-gecko-in-mijlocul-bucurestiului-si-oinvitatie-la-citizen-science.html (accessed 25.06.2021) [in Romanian]

*** Panaitescu D (2019b) Şerpii capitalei. Fauna cum laudae. Revista Radio Guerrilla, https://www.guerrillaradio.ro/revista-guerrilla/serpii-capitalei/ (accessed 25.06.2021) [in Romanian]

*** Panaitescu D (2020) Retrospectiva foto 2020 - în sălbăticie. https://www.dorupanaitescu. ro/retrospectiva-foto-2020-salbaticie.html (accessed 25.06.2021) [in Romanian]

*** Panaitescu D (2021) O posibilă nouă specie pentru fauna țării - Tarentola mauritanica? https://www.dorupanaitescu.ro/posibila-noua-specie-fauna-tarii-tarentola-mauritanica. html (accessed 25.06.2021) [in Romanian]

*** Petruț V (2019) Specie invazivă de broască țestoasă, găsită în Bistrița-Năsăud. Ce spun biologii despre „intrusă“ https://www.observatorbn.ro/2019/03/25/ 
specie-invaziva-de-broasca-testoasa-gasita-in-bistrita-nasaud-ce-spun-biologii-despreintrusa/ (accessed 25.06.2021) [in Romanian]

*** Rotaru M (2017) Broscuțele țestoase din Lacul Bacău, în pericol. https://www.desteptarea. ro/broscutele-testoase-din-lacul-bacau-in-pericol/ (accessed 25.06.2021) [in Romanian]

*** Sos T (2008) (on Testoase.com) Ce specii de testoase apar în pet-shop-urile din Romania? https://testoase.com/forum/viewtopic.php?f=7\&t=1106\&sid=fb8fceb4aec128d9ff4 b7180d5554368 (accessed 25.06.2021) [in Romanian]

*** Știri de Buzău (2017) Lacul din Parcul Tineretului a ajuns raiul broaștelor țestoase. https:// stiridebuzau.ro/actualitate/video-lacul-din-parcul-tineretului-a-ajuns-raiul-broastelortestoase-2407.html (accessed 25.06.2021) [in Romanian]

*** Tarnovschi A (2019) Ce este în realitate peștele piranha prins de un pescar în barajul Firiza. Observator, https://observatornews.ro/eveniment/peste-piranha-baraj-firiza-baiamare-303197.html (accessed 25.06.2021) [in Romanian]

*** TELE’M Botoșani (2017) Pesti si testoase in lacul din parc. https://www.youtube.com/ watch?v=W6ckYpvxQjU (accessed 25.06.2021) [in Romanian]

*** Testoase.com (2016) Specii exotice de testoase NU se elibereaza in Romania! https:// testoase.com/forum/viewtopic.php?f=5\&t=3792 (accessed 25.06.2021) [in Romanian] 